\title{
Molecular Structure of Phenytoin: NMR, UV-Vis and Quantum Chemical Calculations
}

\author{
Raluca Luchian, ${ }^{1}$ Emil Vinţeler, ${ }^{1}$ Cosmina Chiş, ${ }^{2}$ Mihai Vasilescu, ${ }^{1}$ Nicolae Leopold,,${ }^{1}$ Vasile Chişs, ${ }^{1}$ *
}

1 Babeş-Bolyai University, Faculty of Physics, 1 Kogălniceanu, RO-400084 Cluj-Napoca, Romania

2 Iuliu Haţieganu University of Medicine and Pharmacy, 8 Victor Babeş, RO-400012 Cluj-Napoca, Romania

* Corresponding author's e-mail address: vasile.chis@phys.ubbcluj.ro

RECEIVED: October 18, 2015 * REVISED: January 13, 2016 * ACCEPTED: January 14, 2016

THIS PAPER IS DEDICATED TO DR. SVETOZAR MUSIĆ ON THE OCCASION OF HIS 70 $0^{\text {TH }}$ BIRTHDAY

\begin{abstract}
Due to the presence of the carbonyl and imide groups in the structure of 5,5-diphenylhydantoin (DPH), the possibility for this compound to be involved in hydrogen bonding intermolecular interactions is obvious. Even though such interactions are presumably responsible for the mechanism of action of this drug, however, to the best of our knowledge, the self-hydrogen bonding interactions between the DPH monomers have not been addressed till now. Furthermore, studies reporting on the spectroscopic characteristics of this molecule are scarcely reported in the literature.

Here we report on the possible dimers of DPH, investigated by quantum chemical calculations at B3LYP/6-31+G(2d,2p) level of theory. Twelve unique DPH dimers were structurally optimized in gas-phase, as well as in ethanol and DMSO and then were used to compute the population-averaged UV-Vis and NMR spectra using Boltzmann statistics. UV-Vis and NMR techniques were employed to assess experimentally the spectroscopical response of this compound. DFT calculations are also used to investigate the structural transformations between the solid and liquid phase, as well as for describing the electronic transitions and for the assignment of NMR spectra of DPH.
\end{abstract}

Keywords: 5,5-diphenylhydantoin, hydrogen-bonded dimers, electronic transition, NMR.

\section{INTRODUCTION}

$\mathbf{P}$ HENYTOIN (DPH), with the IUPAC name 5,5-diphenylimidazolidine-2,4-dione (see Figure 1 ) and its general chemical formula $\mathrm{C}_{15} \mathrm{H}_{12} \mathrm{~N}_{2} \mathrm{O}_{2}$, is the oldest non-sedative antiepileptic drug ${ }^{[1]}$ indicated for the treatment of epilepsy, ${ }^{[2]}$ decreasing excitatory neurotransmission and enhancing $\gamma$-aminobutyric acid-mediated inhibition. However, despite being extensively used as an active pharmaceutical ingredient for antiepileptic drugs its "biological face" ${ }^{[3]}$ still remains incompletely elucidated.

From a structural point of view, DPH crystallizes in the orthorhombic space group Pn2 ${ }_{1} \mathrm{a}(a=6.230, b=13.581$, $c=15.532 \AA, Z=4)^{[1]}$. Even though the existence of a second polymorph was presumed, ${ }^{[2]}$ recent studies indicated however, that phenytoin crystals obtained from different solvents and in different crystallization conditions do not contain other polymorphs. ${ }^{[4,5]}$ On the other hand, a surface- induced polymorph with enhanced dissolution and orthorhombic system (cell dimensions $a=6.10, b=12.20, c=$ $13.95 \AA$ ) was obtained. ${ }^{[6]}$ Phenytoin also forms binary crystal compounds with copper complexes, ${ }^{[7]}$ polyethylene glycol, ${ }^{[8]}$ pyridone and pyridyl. ${ }^{[9,10]}$

Being highly lipophilic it can be solubilized in alkali and many organic solvents, but, as the free acid, it is poorly soluble in water. ${ }^{[11]}$

Phenytoin acts on sodium channels on the neuronal cell membrane, dampening the unwanted brain activity seen in seizure, by reducing electrical conductance among brain cells. Like for all the anticonvulsant drugs, the distance between the centre of the phenyl ring and carbonyl oxygen is considered important, because both groups are thought to bind to the receptor site on the sodium channel. ${ }^{[12]}$ The modification of hydrogen bonding groups can decrease or even stop the anticonvulsant activity. ${ }^{[13,14]}$ The role of the hydrogen bonding groups is different, the amine 


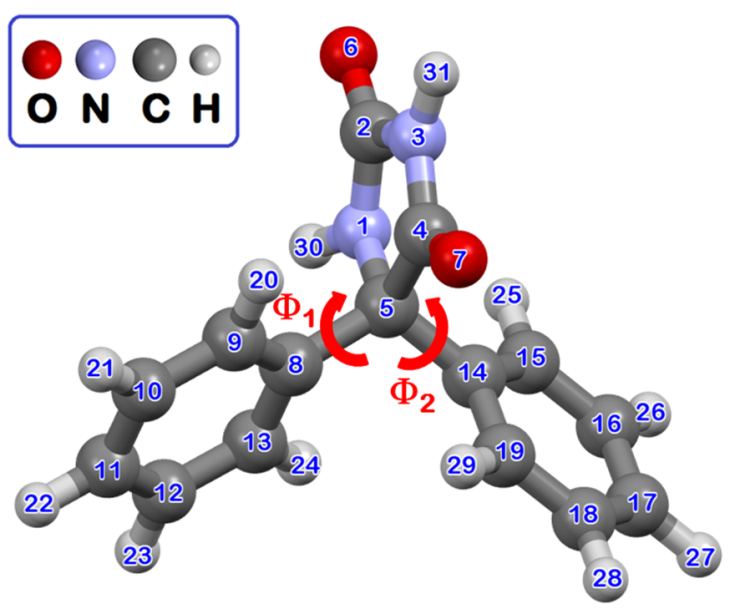

Figure 1. B3LYP/6-31+G(2d,2p) optimized molecular structure of the most stable conformer of phenytoin in gasphase and the atom numbering scheme

N3-H31 and carbonyl C4=07 groups seems to be responsible for its anticonvulsant activity, whereas the amine N1$\mathrm{H} 30$ and carbonyl $\mathrm{C} 2=06$ groups have mutagenic activity. ${ }^{[15]}$

Previously, UV-Vis measurements were used for determining the phenytoin quantity alone ${ }^{[16,17]}$ or in the presence of other drugs. ${ }^{[18,19]}$ Moreover, such data give information about the solubility in different solvents. ${ }^{[20,21]}$ Also, NMR measurements were used to study DPH in solution ${ }^{[22-24]}$ and its binding to model peptide corresponding to a segment of sodium channel. ${ }^{[25]}$

All these findings prompted us to study the dimerization process of DPH through hydrogen bonding interactions. Thus, a thorough conformational analysis of the dimeric species following the Boltzmann's distribution law is presented in this work. Moreover, combining the experimental UV-Vis and NMR techniques with quantum chemical calculations we addressed the effect of such hydrogen bonding interactions on the electronic transitions as well as on the NMR chemical shifts of DPH.

\section{Experimental Details}

DPH of $99 \%$ purity was purchased from a standard commercial source (Alfa Aesar) and used without further purification.

Optical absorbance spectra of DPH in ethanol were recorded at room temperature using a Jasco V-670 UV-VisNIR spectrophotometer with a slit width of $2 \mathrm{~nm}$.

The ${ }^{1} \mathrm{H}$ and ${ }^{13} \mathrm{C}$ NMR spectra were recorded at room temperature on a Bruker AVANCE NMR spectrometer (400.13 MHz for ${ }^{1} \mathrm{H}$ and $100.63 \mathrm{MHz}$ for ${ }^{13} \mathrm{C}$, internal standard TMS). The samples were prepared by the dissolution of DPH in DMSO (signal for ${ }^{1} \mathrm{H}$ at $2.51 \mathrm{ppm}$ and at $39.45 \mathrm{ppm}$ and for ${ }^{13} \mathrm{C}$ ). The spectra were recorded using a single excitation pulse of $11 \mu \mathrm{s}$ for ${ }^{1} \mathrm{H}$ and $7.5 \mu$ s for ${ }^{13} \mathrm{C}$.

\section{Computational Details}

The optimization of DPH geometry and single point calculations were performed with the Gaussian 09, revision C.01 software package ${ }^{[26]}$ by using DFT approaches. The hybrid B3LYP exchange-correlation functional[ ${ }^{[27-30]}$ was used in conjunction with Pople's split-valence $6-31+G(2 d, 2 p)$ basis set. ${ }^{[31,32]}$ Default criteria were used to define the convergence of both the electronic density and molecular geometries. Stationary points were characterized by analytical frequency calculations.

Absorption spectra of DPH were calculated using the time-dependent DFT (TD-DFT) methodology, ${ }^{[33]}$ implemented in the Gaussian09 package, which describes the excited states in terms of all possible single excitations from occupied to virtual orbital. These spectra have been calculated on DPH optimized structures at B3LYP /6-31+G $(2 d, 2 p)$ level of theory. The nature of the excited states has been analyzed using the Natural Transition Orbitals (NTO) formalism proposed by Martin. ${ }^{[34]}$ This formalism offers compact description of the electronic excitations with the advantage that only one or two occupied/virtual pairs of orbitals are enough for a clear interpretation of the physical nature of the excited states involved in absorption and emission processes. [35-39]

The calculation of NMR chemical shifts for DPH was performed using the GIAO (Gauge-Including Atomic Orbital) method, ${ }^{[40,41]}$ implemented in the Gaussian09 package, with the B3LYP exchange-correlation functional, in conjunction with $6-31+G(2 d, 2 p)$ basis set. In order to express the chemical shifts in terms of the total computed NMR shielding tensors, TMS (tetramethylsilane) shielding tensors were calculated at the same level of theory.

The solvent effects have been considered by using the implicit Polarizable Continuum Model (PCM) ${ }^{[42]}$ using the integral equation formalism (IEFPCM) variant. ${ }^{[43]}$

\section{RESULTS AND DISCUSSION}

\section{Hydrogen Bonds}

Two minimum energy structures are possible for the DPH monomer, i.e., the structure shown in Figure 1 (denoted as A conformer) and its mirror image (B conformer). Obviously, these two minima are equivalent from energetic and spectroscopic point of view. However, both of them must be considered when forming the possible dimers of DPH.

For conformer A, the left (C8-C9) ring is almost coplanar with the $\mathrm{C} 4-\mathrm{C} 5$ bond of the hydantoin unit, while the second phenyl ring (C14-C15) is approximately coplanar with the $\mathrm{C} 5-\mathrm{N} 1$ bond. Due to the presence of the two $\mathrm{NH}$ groups as hydrogen bond donors and two oxygens as hydrogen bond acceptors, different hydrogen bonded dimers can be formed. We were interested only in these type 
Table 1 Dihedral angles and hydrogen bond lengths characterizing the DPH monomer and dimers in gas-phase, ethanol and DMSO (first, second and third entry, respectively) at B3LYP/6-31+G $(2 d, 2 p)$. The dihedral angles $\Phi_{1}$ and $\Phi_{2}$ correspond to the first monomer and $\Phi_{1}{ }^{\prime}$ and $\Phi_{2}{ }^{\prime}$ correspond to the second monomer in the dimer. Experimental data for the known solid state structure of DPH are included for comparison purposes.

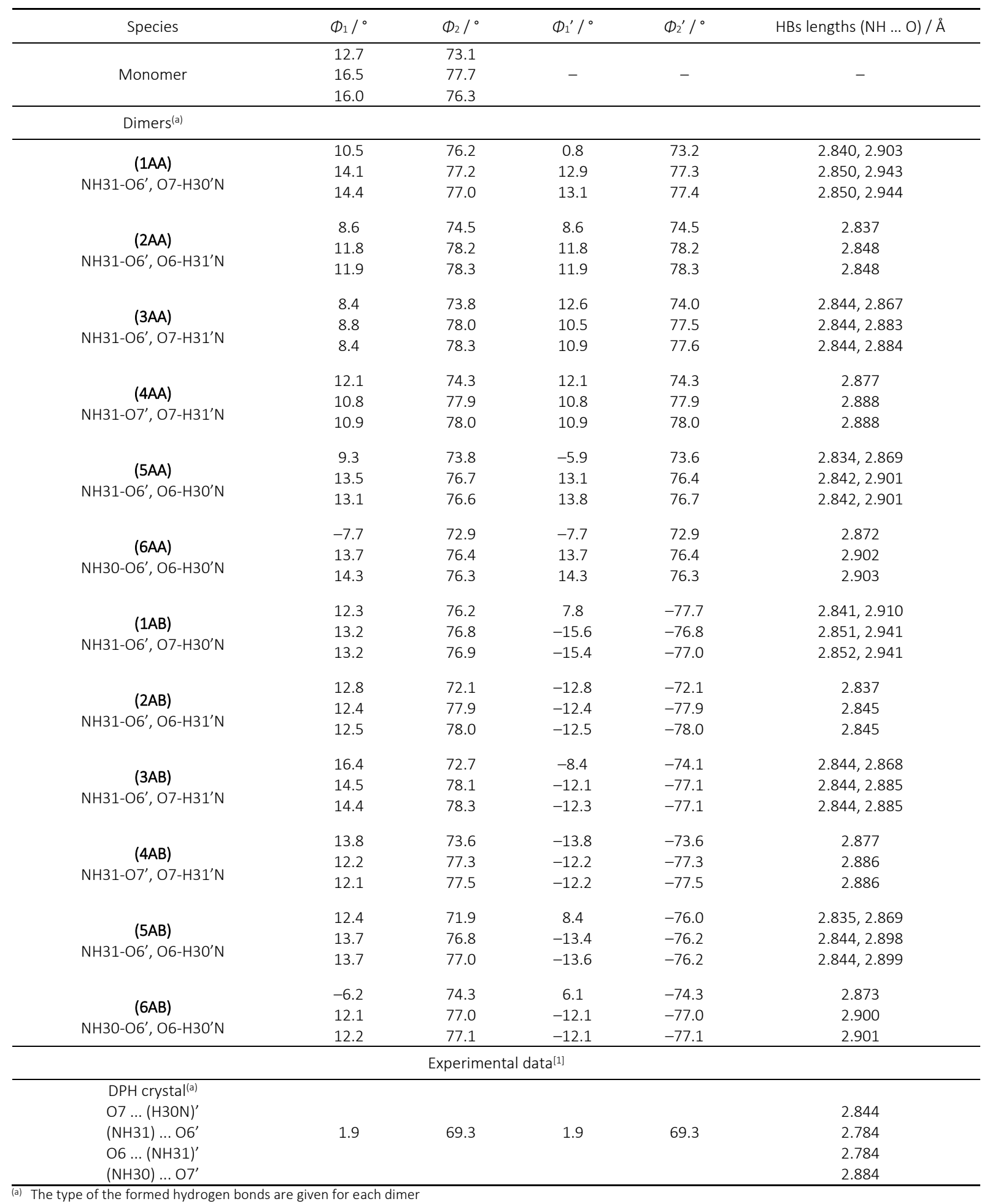




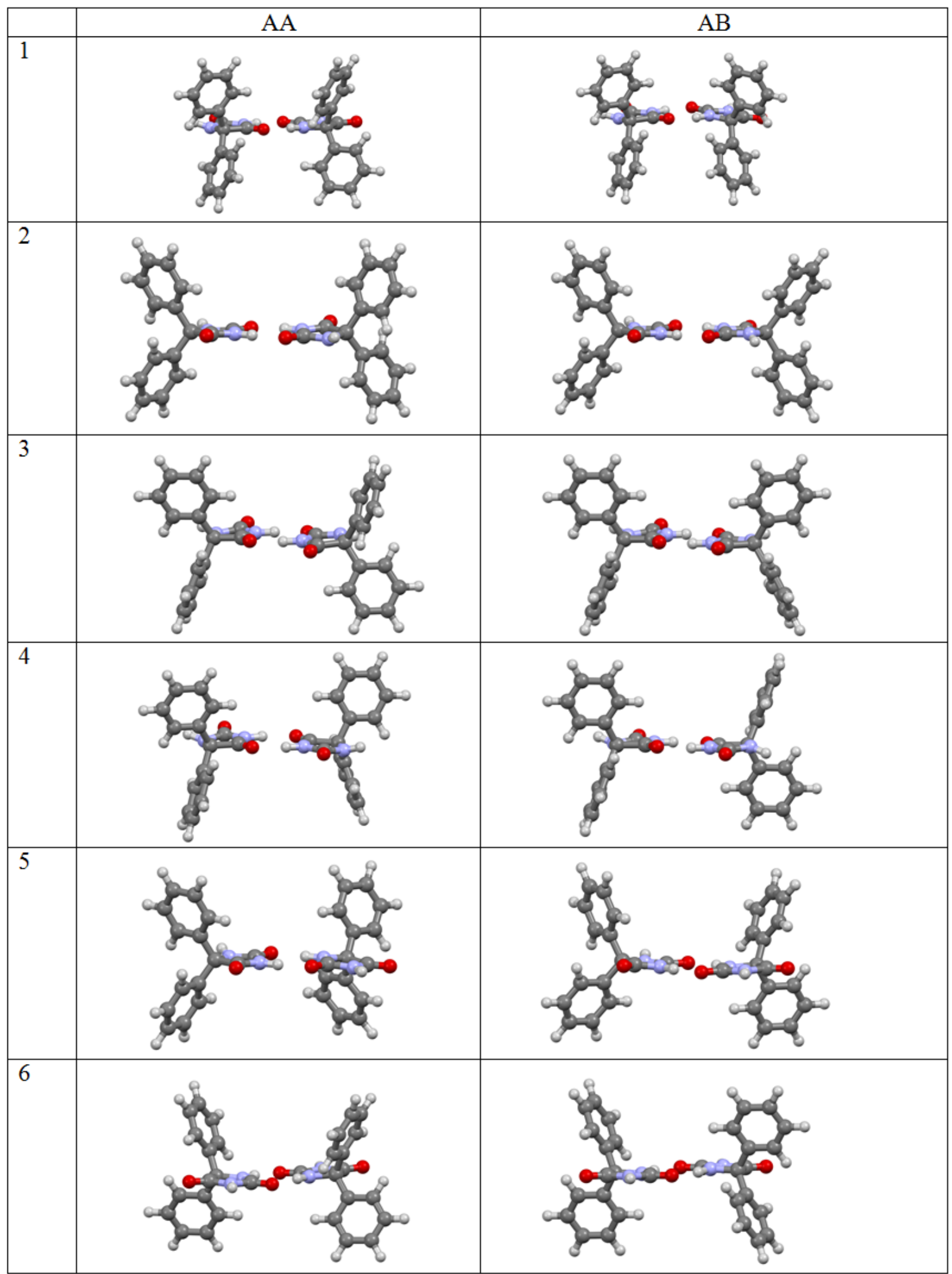

Figure 2. B3LYP/6-31+G(2d,2p) optimized structures for the twelve dimers of 5,5-diphenylhydantoin in gas-phase. 
of dimers because they are significantly more stable than other types of dimers, formed for instance by dispersion interactions. Moreover, only the double hydrogen bonded dimers were considered because it is expected that the geometry of single hydrogen bonded dimers will converge to a double $\mathrm{H}$ bonded structure.

A total number of 12 double hydrogen bonded unique dimers can be formed, of which 6 are of $A A$ type and 6 of $A B$ type. The $B B$ and $B A$ type dimers were not considered because they are mirror images of the $A A$ and $A B$ types, respectively. The conformations of the 12 unique dimers are shown in Figure 2 and some of their selected structural parameters are reported in Table 1 (see Table S2 in the Electronic Supplementary Information for Cartesian coordinates of their optimized geometries).

The geometries of the dimers were fully optimized and all of them correspond to minima on the potential energy surface. It is worth mentioning that the geometries of the $2 A A, 4 A A$ and $6 A A$ dimers have $C_{2}$ symmetry, while those of the $2 A B, 4 A B$ and $6 A B$ dimers are of $C_{i}$ symmetry.

We shall first briefly discuss the structural characteristics of the monomer for which geometrical parameters have been reported by Camerman et al. ${ }^{[1]}$ and discussed also by Tamir et al. ${ }^{[22]}$ As seen in Table 1, for the gas-phase molecule, the calculated angles which define the relative orientation of the two phenyl rings with respect to the hydantoin unit $\left(\Phi_{1}=\right.$ C4C5C8C9, $\Phi_{2}=$ C4C5C14C19) are in qualitative agreement with the experimental data, as already observed by Tamir et al. ${ }^{[22]}$ Even a quantitative agreement is observed for $\Phi_{2}$, while $\Phi_{1}$ is slightly worse reproduced. These calculated angles do not change appreciably in the two solvents, a very small increase (cca. $4{ }^{\circ}$ ) being observed for both angles. Even though the dissolution of the compound is likely to be accompanied by a conformational change of the molecule, however, the present results suggest only a minor modification of the $\Phi_{1}$ angle when going from solid to liquid state.
The angles between the planes defined by the phenyl groups and the hydantoin unit are presented in Table 2 . The best agreement between the experimental and calculated data is again noted for the gas-phase molecule, particularly for the (Ph2,Hyd) dihedral angle. According to quantum chemical calculations, in liquid phase, the angle between the Ph1 and Hyd planes is only slightly changed with respect to gas-phase. On the other hand, the dihedral angle (Ph1,Ph2) decreases in solution, simultaneously with a slight increase of the (Ph2,Hyd) angle.

An improved description for the solid state structure could be achieved by using a cluster of molecules able to describe all the four hydrogen bonds involving at least one monomer and also, by considering the dispersion interactions; such an analysis is, however, beyond the scope of this study.

According to Carter et al., ${ }^{[44]}$ the distance between the centroids of the phenyl rings and the carbonyl oxygen atoms seem to play a dominant role for the binding mechanism of DPH to the receptor in the sodium channel.

As seen in Table 2, these distances are not much affected by the transition between the gas-phase and liquid phase. With respect to the solid state structure, ${ }^{[1]}$ in ethanol and DMSO, the distances between the $\mathrm{O} 7$ atom and the two centroids $X 1$ and $X 2$ increase very slightly. The same trend is observed for the distances from 06 to the two centroids.

Regarding the dimers of DPH, the hydrogen bond length reported in the last column of Table 1 is the distance between the corresponding nitrogen and oxygen atoms. First, as it comes out from Table 1, there is no qualitative difference between the geometric al parameters that characterize the relative orientation of the phenyl rings to the hydantoin unit for the dimeric structures in gas-phase and ethanol. Moreover, for ethanol and DMSO solutions, the $\Phi$ angles and hydrogen bonding distances are almost identical. On the other hand, the hydrogen bond distances for the gas-phase structures are constantly shorter than for corresponding solvated dimers.

Table 2. Calculated angles between planes and distances between the ring centroids and oxygen atoms for DPH monomer in gas-phase, ethanol and DMSO

\begin{tabular}{|c|c|c|c|c|}
\hline Parameter ${ }^{(a)}$ & gas-phase & ethanol & DMSO & X-ray data ${ }^{[1]}$ \\
\hline$\angle(\mathrm{Ph} 1, \mathrm{Ph} 2) /^{\circ}$ & 81.59 & 76.03 & 77.57 & 89.56 \\
\hline$\angle(\mathrm{Ph} 1, \mathrm{Hyd}) /^{\circ}$ & 73.32 & 73.87 & 73.73 & 65.67 \\
\hline$\angle(\mathrm{Ph} 2, \mathrm{Hyd}) /^{\circ}$ & 66.98 & 70.86 & 69.87 & 65.95 \\
\hline$d(\mathrm{X} 107) / \AA$ & 4.263 & 4.250 & 4.253 & 4.226 \\
\hline$d(\mathrm{X} 2 \mathrm{O} 7) / \AA$ & 4.012 & 4.002 & 4.003 & 3.968 \\
\hline$d(\mathrm{X} 106) / \AA$ & 5.473 & 5.531 & 5.528 & 5.513 \\
\hline$d(\mathrm{X} 2 \mathrm{O} 6) / \AA$ & 5.779 & 5.711 & 5.715 & 5.677 \\
\hline
\end{tabular}

(a) Ph1, Ph2 and Hyd are the planes defined by C8-C13 phenyl ring, C14-C19 phenyl ring and hydantoin ring, respectively; X1 and X2 are the centroids of the two phenyl rings. 
Thus, the same geometry is predicted for the same kind of dimers in the two solvents, which is slightly different from that predicted for the gas-phase.

It is reasonable to assume that the strength of the $\mathrm{HB}$ interactions will play a major role in the stability of the dimers. This is indeed true for the solvated dimers in which case the dimeric structures with the shortest (averaged) HB distance ( $2 A B$ dimer) are the most stable, the situation being is mirrored for the gas-phase structures. For the latter ones, the most stable, nearly isoenergetic dimers $2 A A$ and $2 A B$ have an averaged $\mathrm{HB}$ distance of $2.837 \AA$, significantly shorter than the immediately higher in energy dimers $6 A B$ and $5 A B$.

The intermolecular hydrogen bonding in the most stable dimer $2 \mathrm{AA}$ lead to the increase of the $\mathrm{N}-\mathrm{H}$ and $\mathrm{C}=\mathrm{O}$ bond lengths by about 0.021 and $0.014 \AA$, respectively, with respect to the monomer. For example, the $\mathrm{N} 1-\mathrm{H} 30$ bond is lengthened from $1.009 \AA$ to $1.030 \AA$ and $\mathrm{C} 2=06$ bond from $1.210 \AA$ to $1.224 \AA$. The $\mathrm{X}$-ray study ${ }^{[1]}$ shows that in the crystal lattice, the N1-H30 bond and N3-H31 bond is $0.93 \AA$ and $0.809 \AA$ respectively and $\mathrm{C} 4=07$ bond and $\mathrm{C} 2=06$ bond is $1.222 \AA$ and $1.209 \AA$ respectively. The differences appear because DPH molecule is involved in two hydrogen bonds in all the investigated dimers but in solid state each monomer is connected to four neighbor molecules, making two pairs of equivalent hydrogen bonds of 2.784 and $2.884 \AA$ (see Figure S1 in ESI).

Relative Boltzmann populations are calculated using the formula:

$$
P_{i}=\frac{g_{i} e^{\left(-\frac{\Delta E_{i}}{k_{\mathrm{B}} T}\right)}}{\sum_{i} g_{i} e^{\left(-\frac{\Delta E_{i}}{k_{\mathrm{B}} T}\right)}}
$$

where $\Delta E_{i}$ are the relative energies corrected for zero-point vibrational energies $\left(\Delta E_{\mathrm{ZPVE}}\right), k_{\mathrm{B}}$ is the Boltzmann constant, $\mathrm{T}$ is the temperature $(T=298 \mathrm{~K})$ and $\mathrm{g}_{\mathrm{i}}$ are the degeneracy degrees for each conformer $\left(g_{i}=2\right.$ for $C_{1}$ symmetry and $g_{i}=1$ for $C_{2}$ and $C_{i}$ symmetries). ${ }^{[45-47]}$

As shown in Table 3, our calculations predict a dramatic change in the pattern of relative energies of some dimers when going from gas-phase to liquid-phase. However, the two $2 A A$ and $2 A B$ dimers are the most stable both, in gas-phase and liquid phase. On the other hand, due to the symmetry degeneracy, the largest relative Boltzmann populations are predicted for the $5 A B$ and $5 A A$ dimers in gas phase, but the largest contributions to the spectroscopic properties in solution are predicted for the dimers of type 2,3 and 5 , either $A A$ or $A B$. Particularly, the $2 A B$ and $2 A A$ dimers, which are the most stable in liquid phase contribute together almost $30 \%$ of the total population in solution. In ethanol and DMSO solvents, the dimers $2 A B, 2 A A$, $3 A A, 3 A B, 5 A A$ and $5 A B$ are within a $0.59 \mathrm{kcal} \mathrm{mol}^{-1}$, which is less than the room temperature energy. Even though significantly higher in energy, due to the symmetry degeneracy, the dimers $1 \mathrm{AA}$ and $1 \mathrm{AB}$ have appreciable relative populations higher, than $5 \%$. In such cases, the calculated spectra must include the responses from all species, weighted by their Boltzmann factors. ${ }^{[45-52]}$ For this reason we calculated the electronic absorption and NMR spectra of DPH considering the dimers with relative populations greater than $5 \%$.

\section{UV-Vis Spectrum}

The UV-Vis spectra of DPH in ethanol (see Figure 3) were recorded at five concentrations, ranging from $10^{-5} \mathrm{M}$ to $10^{-}$ ${ }^{4} \mathrm{M}$. A slight red-shift from $204 \mathrm{~nm}$ to $211 \mathrm{~nm}$ was observed for $\lambda_{\max }$ by increasing the concentration.

Table 3. Relative energies (ZPE corrected) and Boltzmann populations of the twelve DPH dimers in gas-phase (B3LYP/6$31+G(2 d, 2 p)$ level of theory) and in ethanol and DMSO (PCM-B3LYP/6-31+G(2d,2p) level of theory), at room temperature

\begin{tabular}{|c|c|c|c|c|c|c|}
\hline \multirow[b]{2}{*}{ Dimer } & \multicolumn{2}{|c|}{ Gas } & \multicolumn{2}{|c|}{ Ethanol } & \multicolumn{2}{|c|}{ DMSO } \\
\hline & $\Delta E_{\mathrm{ZPE}} / \mathrm{kcal} \mathrm{mol}^{-1}$ & Population / \% & $\Delta E_{\mathrm{ZPE}} / \mathrm{kcal} \mathrm{mol}^{-1}$ & Population / \% & $\Delta E_{\mathrm{ZPE}} / \mathrm{kcal} \mathrm{mol}^{-1}$ & Population / \% \\
\hline $1 \mathrm{AA}$ & 1.22 & 3.62 & 0.98 & 5.75 & 1.04 & 5.54 \\
\hline $2 \mathrm{AA}$ & 0.00 & 14.26 & 0.02 & 14.46 & 0.06 & 14.19 \\
\hline 3AA & 1.09 & 4.50 & 0.46 & 13.85 & 0.46 & 14.41 \\
\hline $4 \mathrm{AA}$ & 2.07 & 0.44 & 1.28 & 1.73 & 1.27 & 1.83 \\
\hline $5 \mathrm{AA}$ & 0.24 & 19.13 & 0.53 & 12.28 & 0.58 & 11.81 \\
\hline $6 \mathrm{AA}$ & 0.36 & 7.77 & 1.28 & 1.74 & 1.36 & 1.58 \\
\hline $1 \mathrm{AB}$ & 1.47 & 2.39 & 1.02 & 5.36 & 1.03 & 5.50 \\
\hline $2 A B$ & 0.01 & 14.02 & 0.00 & 15.07 & 0.00 & 15.66 \\
\hline $3 A B$ & 1.20 & 3.79 & 0.47 & 13.63 & 0.48 & 13.93 \\
\hline $4 A B$ & 2.11 & 0.40 & 1.23 & 1.90 & 1.21 & 2.03 \\
\hline $5 A B$ & 0.22 & 19.72 & 0.54 & 12.17 & 0.59 & 11.63 \\
\hline $6 \mathrm{AB}$ & 0.21 & 9.97 & 1.18 & 2.06 & 1.26 & 1.88 \\
\hline
\end{tabular}


The excitation energies of the DPH monomer in ethanol were calculated using the TD-DFT approach and they are listed in Table 4. To better understand the properties of the excited states of DPH we obtained the NTOs based on the calculated dens ity $\mathrm{m}$ atrices. It is a common practice to denote the occupied NTOs as "hole transition orbitals" and the unoccupied NTOs as "particle transition orbitals". ${ }^{[35,37,38,53,54]}$ Figure 4 illustrates the NTOs for the main electronic transitions of DPH monomer in ethanol.

Thus, according to theoretical results, the most intense electronic transitions of the DPH monomer are predicted in UV region, in very good agreement with the experimental data. Quantum chemical calculations give a clear picture of the emergence of electronic transitions. Thus, as observed in Table 4, the main contribution to $\mathrm{SO} \rightarrow$ $\mathrm{S} 1$ transition is the HOMO-LUMO excitation. From Figure 4 it is seen that the hole is delocalized on the entire molecule, while the particle NTO is much more localized onto the hydantoin unit. Consequently, we assign this transition to the intra-molecular charge transfer between the phenyl rings and hydantoin group.

The next 7 allowed excited states with appreciable oscillator strength are higher in energy but very close to each other, spanning a wavelength interval as low as 14.7 $\mathrm{nm}$. As seen in Figure 4, excepting the S13 and S14, all the other excitations contain a major part of $\pi \pi^{*}$ transitions with HOTO localized on one of the two phenyl rings and LUTO on the other phenyl. On the other hand, S13 state appears as a result of a dominant excitation which involves a transfer of the electronic density from the hydantoin to one of the phenyl rings, while S14 involves a redistribution of the electronic density between the two phenyls, as well as the hydantoin unit.

The calculated oscillator strengths are proportional to the strengths of the observed electronic transition and consequently to the intensities of experimental absorption bands ${ }^{[3,55,56]}$ (see Figure 3 ). The inset in the Figure 3 shows the deconvolution of the experimental UV spectrum at $7.5 \cdot 10^{-5} \mathrm{M}$ concentration, with peaks at $204 \mathrm{~nm}, 209 \mathrm{~nm}$, $216 \mathrm{~nm}$ and $230 \mathrm{~nm}$.

The first three deconvoluted peaks can be put in correspondence with the first three simulated absorbance bands. Only the last deconvoluted peak at $230 \mathrm{~nm}$ is shifted appreciably to lower wavelengths compared to the simulated absorbance band peak located at $247 \mathrm{~nm}$.

Based on present calculations we assume that for concentrations lower than $5 \cdot 10^{-5} \mathrm{M}$ the dominant contributions to the absorption spectrum is mos tly due to the monomers, and the experimental peak is given by the absorption band calculated for monomers at 201-208 nm (see Table 4). A clear asymmetry of the absorption curves is observed for all concentrations. We find that they hide a shoulder near $230 \mathrm{~nm}$ that can be recovered by deconvolution (see the inset in Figure 3).

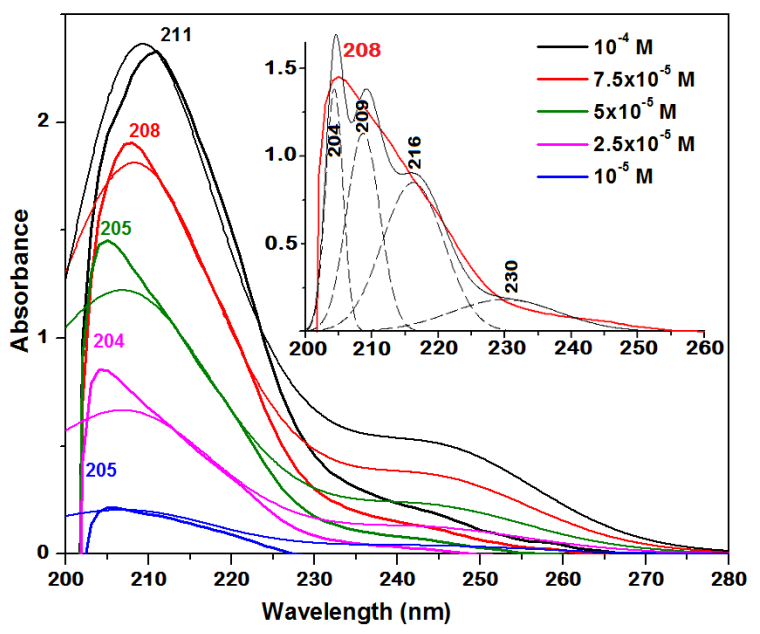

Figure 3. Experimental (solid line) and simulated (dashed line) UV-Vis spectra of DPH in ethanol at five concentrations. Simulated spectra have been calculated for DPH monomer and the eight most stable dimers in ethanol, whose cumulated Boltzmann population is $92.6 \%$ (see Tables 4 and $\mathrm{S} 1)$. In the inset is illustrated the deconvoluted experimental curve recorded at $7.5 \cdot 10^{-5} \mathrm{M}$.

The red-shift of $\lambda_{\max }$ (from $205 \mathrm{~nm}$ to $211 \mathrm{~nm}$ ), observed as a result of increasing the concentration, can be explained by the increase in dimer population, which is assumed to occur when the concentration increases from $5 \cdot 10^{-5}$ to $10^{-4} \mathrm{M}$. For this reason we simulated the absorption spectrum of DPH as the sum of absorbance contributions of the dimers in ethanol, whose populations were greater than $5 \%$, weighted by their Boltzmann population at room temperature, and using a full width at half maximum of $0.26 \mathrm{eV}$. For this purpose we considered the $2 A B$, $2 A A, 3 A A, 3 A B, 5 A A, 5 A B, 1 A A$ and $1 A B$ dimers, with a total relative population of $92.6 \%$.

According to the calculated relative free energies given in Table 3, the DPH dimers $2 A B$ and $2 A A$ are the most stable and most abundant in ethanol. UV spectrum of DPH dimer $2 A B$ has four absorption bands, at 207-212 nm $(f=0.04-0.099)$, due to $\mathrm{HOMO} \rightarrow$ LUMO +3 , HOMO $-1 \rightarrow$ LUMO $+n$ with $n=2,7$ and HOMO- $11+n \rightarrow$ LUMO $+n$ with $n=$ 0,1 ; at $216(f=0.11)$, due to HOMO-2 $\rightarrow$ LUMO+2; at 224.5 $(f=0.069)$, due to HOMO $\rightarrow$ LUMO+3 and HOMO$1 \rightarrow$ LUMO+2; and at $248 \mathrm{~nm}(f=0.134)$ due to $\mathrm{HOMO} \rightarrow$ LUMO and HOMO-1 $\rightarrow$ LUMO+1. Expectedly, the UV spectra of the other seven dimers (listed in Table S1) have similar electronic absorptions with those of $2 A B$ dimer, in the same wavelength regions. Based on monomer and dimer model calculations we consider that the experimental peak at $\lambda=205 \mathrm{~nm}$ in Figure 3 indicates the absorption by $100 \%$ population of monomers; Also, the monomer population is dominant for concentrations lower than $5 \cdot 10^{-5} \mathrm{M}$. 
Table 4. Theoretical UV-Vis absorption spectral data calculated for the DPH monomer and dimer $2 \mathrm{AB}$ in ethanol at B3LYP/6$31+\mathrm{G}(2 \mathrm{~d}, 2 \mathrm{p})$ level of theory

\begin{tabular}{|c|c|c|c|c|c|}
\hline Species & Excited state & $\lambda / \mathrm{nm}$ & $f^{(a)}$ & transitions $s^{(b)}$ & Contributions / \%(c) \\
\hline \multirow[t]{16}{*}{ Monomer } & S1 & 246.6 & 0.066 & $\mathrm{H} \rightarrow \mathrm{L}$ & 52 \\
\hline & & & & $\mathrm{H}-1 \rightarrow \mathrm{L}$ & 21 \\
\hline & S9 & 216.1 & 0.054 & $\mathrm{H}-1 \rightarrow \mathrm{L}+1$ & 31 \\
\hline & & & & $\mathrm{H}-1 \rightarrow \mathrm{L}+2$ & 21 \\
\hline & S12 & 211.4 & 0.040 & $\mathrm{H}-1 \rightarrow \mathrm{L}+3$ & 31 \\
\hline & & & & $\mathrm{H}-3 \rightarrow \mathrm{L}+2$ & 17 \\
\hline & S13 & 208.9 & 0.061 & $\mathrm{H}-5 \rightarrow \mathrm{L}$ & 33 \\
\hline & & & & $\mathrm{H}-2 \rightarrow \mathrm{L}+2$ & 21 \\
\hline & S14 & 207.7 & 0.113 & $\mathrm{H} \rightarrow \mathrm{L}+4$ & 31 \\
\hline & S15 & 207.5 & 0.052 & $\mathrm{H}-5 \rightarrow \mathrm{L}$ & 20 \\
\hline & & & & $\mathrm{H}-1 \rightarrow \mathrm{L}+4$ & 19 \\
\hline & S16 & 205.0 & 0.065 & $\mathrm{H}-3 \rightarrow \mathrm{L}+2$ & 25 \\
\hline & & & & $\mathrm{H}-4 \rightarrow \mathrm{L}+1$ & 25 \\
\hline & S18 & 201.4 & 0.058 & $\mathrm{H}-2 \rightarrow \mathrm{L}+3$ & 30 \\
\hline & & & & $H-2 \rightarrow L+4$ & 20 \\
\hline & & & & $\mathrm{H}-4 \rightarrow \mathrm{L}+1$ & 18 \\
\hline \multirow[t]{10}{*}{$2 \mathrm{AB}$ dimer } & S1 & 247.9 & 0.134 & $\mathrm{H} \rightarrow \mathrm{L}$ & 29 \\
\hline & & & & $\mathrm{H}-1 \rightarrow \mathrm{L}+1$ & 24 \\
\hline & S15 & 224.5 & 0.069 & $\mathrm{H} \rightarrow \mathrm{L}+3$ & 27 \\
\hline & & & & $\mathrm{H}-1 \rightarrow \mathrm{L}+2$ & 26 \\
\hline & S22 & 216.1 & 0.110 & $\mathrm{H}-2 \rightarrow \mathrm{L}+2$ & 15 \\
\hline & S27 & 212.1 & 0.040 & $\mathrm{H}-1 \rightarrow L+2$ & 18 \\
\hline & & & & $\mathrm{H} \rightarrow \mathrm{L}+3$ & 17 \\
\hline & S31 & 211.3 & 0.099 & $\mathrm{H}-1 \rightarrow \mathrm{L}+7$ & 15 \\
\hline & S42 & 207.1 & 0.051 & $\mathrm{H}-10 \rightarrow \mathrm{L}+1$ & 17 \\
\hline & & & & $\mathrm{H}-11 \rightarrow \mathrm{L}$ & 16 \\
\hline
\end{tabular}

\footnotetext{
(a) only transitions with $\mathrm{f}>0.04$ are included

(b) $\mathrm{H}-\mathrm{HOMO}$ and $\mathrm{L}-\mathrm{LUMO}$

(c) only contributions $>15 \%$ are included
}

The intermediate UV curve with the peak at $\lambda=208 \mathrm{~nm}$ is the result of absorption of a mixed population of $50 \%$ monomers and $50 \%$ dimers. The experimental peak at $\lambda=$ $211 \mathrm{~nm}$ is due to a $100 \%$ population of dimers.

\section{NMR Analysis}

The optimized structure of DPH conformer in gas phase was re-optimized in DMSO by considering the solvent effect using the polarized continuum model (PCM). Calculation of vibrational frequencies has confirmed that the unique structure is a stationary point with no negative eigenvalue observed in the force constant matrix. The theoretical chemical shifts are derived from the total computed NMR shielding tensors by using the TMS (tetramethylsilane) shielding tensors as reference. The experimental and calculated (population averaged) chemical shifts, both for monomer and the twelve investigated dimers of DPH in DMSO, are listed in Table 5 (the mean absolute error (MAE) values are also included). The computed chemical shifts for each of the eight most stable dimers are given in Table 6 (their cumulated Boltzmann population is $92.7 \%$ ). The experimental ${ }^{1} \mathrm{H}$ NMR spectrum of DPH in DMSO shows two peaks (each of integral 1) located at 9.39 and $11.18 \mathrm{ppm}$ which are due to the $\mathrm{H} 31$ and $\mathrm{H} 30$ protons, respectively (see Figure 1 for atom numbering scheme).

The other two peaks at $7.35 \mathrm{ppm}$ (integral: 2) and $7.41 \mathrm{ppm}$ (integral: 8) can easily be assigned to the phenyl protons, as shown in Table 5.

When the ${ }^{13} \mathrm{C}$ NMR spectrum of the molecule is considered, it is seen that two downfield peaks due to the most de-shielded carbon nuclei $\mathrm{C} 4$ and $\mathrm{C} 2$ are located at 174.81 ppm and 156.00 ppm, while the most shielded $C 5$ nucleus gives a peak at $70.22 \mathrm{ppm}$. In this spectrum, the peak due to equivalent alkenal carbon atoms $\mathrm{C} 8$ and $\mathrm{C} 14$ (in the phenyl rings) bonded to the carbon atom in hydantoin is located at $139.90 \mathrm{ppm}$, while for the remaining carbon nuclei 


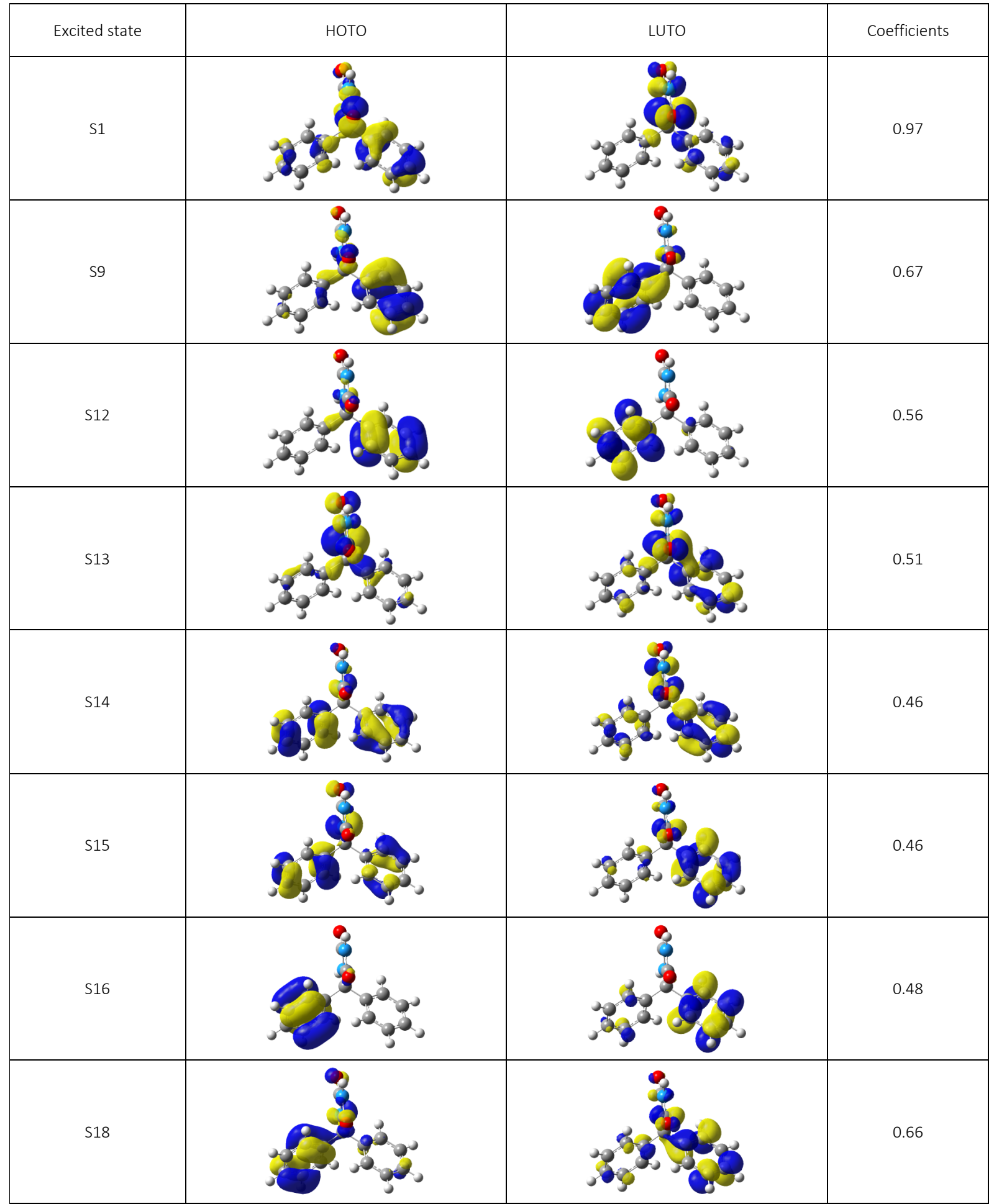

Figure 4. B3LYP/6-31+G(2d,2p) calculated hole (HOTO) and particle (LUTO) natural transition orbitals (isovalue 0.04 a.u.), as well as their coefficients, involved in the electronic transitions with appreciable oscillator strength for DPH monomer in ethanol. Shown are only the HOTO-LUTO pairs which contribute the most to each particular excitation. The NTO coefficients represent the extent to which the excitation can be written as a single configuration[35]. 
Table 5. Experimental and theoretical chemical shifts (in ppm) for DPH in DMSO

\begin{tabular}{|c|c|c|c|}
\hline \multirow{2}{*}{ Atoms } & \multirow{2}{*}{$\begin{array}{l}\text { Experimental } \\
\operatorname{data}^{(a)}\end{array}$} & \multicolumn{2}{|c|}{ Theoretical data ${ }^{(b)}$} \\
\hline & & Monomer & Dimer \\
\hline C4 & 174.81 & 174.73 & 174.40 \\
\hline C2 & 156.00 & 153.99 & 156.32 \\
\hline $\mathrm{C} 8, \mathrm{C} 14$ & 139.90 & 138.87 & 139.71 \\
\hline $\mathrm{C} 10, \mathrm{C} 12, \mathrm{C} 16, \mathrm{C} 18$ & 128.45 & 126.89 & 126.46 \\
\hline $\mathrm{C} 11, \mathrm{C} 17$ & 127.98 & 126.70 & 126.48 \\
\hline $\mathrm{C9}, \mathrm{C} 13, \mathrm{C} 15, \mathrm{C} 19$ & 126.57 & 126.14 & 126.11 \\
\hline C5 & 70.22 & 77.70 & 76.96 \\
\hline H31 & 11.18 & 8.40 & 11.50 \\
\hline $\mathrm{H} 30$ & 9.39 & 6.67 & 5.64 \\
\hline $\mathrm{H} 22, \mathrm{H} 27$ & 7.35 & 7.99 & 7.75 \\
\hline $\begin{array}{c}\mathrm{H} 20, \mathrm{H} 21, \mathrm{H} 23-\mathrm{H} 26, \\
\mathrm{H} 28, \mathrm{H} 29\end{array}$ & 7.41 & 7.84 & 7.70 \\
\hline MAE & & 1.86 & 1.49 \\
\hline \multicolumn{4}{|c|}{$\begin{array}{l}\text { a) The NMR }{ }^{1} \mathrm{H} \text { and }{ }^{13} \mathrm{C} \text { data of DPH in DMSO with respect to the TM } \\
\text { reference values. } \\
\text { b) The chemical shifts calculated at B3LYP/6-31+G(2d,2p) level of theory witt } \\
\text { respect to TMS reference values; dimer data were derived as a weighte } \\
\text { average of the chemical shifts calculated for the eight most stable dimer } \\
\text { of DPH in DMSO whose cumulated Boltzmann population is } 92.7 \% \text { (se } \\
\text { Table 6). }\end{array}$} \\
\hline
\end{tabular}

in the phenyl rings, the corresponding three peaks are found between 126.57 and $128.45 \mathrm{ppm}$. As can be seen in Table 5, the main differences between experimental values and those calculated for monomer are noted for the $\mathrm{C} 5 \mathrm{nu}$ cleus as well as for the $\mathrm{H} 30$ and $\mathrm{H} 31$ protons. The hydrogen- bonding interactions can affect the shielding of $\mathrm{H} 30$ and $\mathrm{H} 31$ protons. This is indeed the case, and dimer calculations show that these intermolecular interactions modify the charge density of the hydantoin unit, having as a result the significant change of the chemical shift of $\mathrm{C} 2$ and $\mathrm{H} 31$ nuclei and to a smaller extent for the $\mathrm{H} 30$ nucleus. The value of chemical shift for the $\mathrm{C} 5$ nucleus in dimer improves only slightly compared to the monomer case. The reason must be that the $\mathrm{C} 5$ nucleus is shielded by the phenyl rings more strongly than predicted by the PCM continuum solvation model. As seen in Table 6, the $5 A B$ and $1 A B$ dimers provide an improved agreement between the experimental and calculated chemical shift for $\mathrm{H} 30$ proton, at the expense of a worse agreement for the $\mathrm{H} 31$ proton. Nevertheless, the corresponding calculated values for the individual dimers, as well as the weighted average are unacceptably away from the experimental counterparts. This discrepancy can be attributed to the non-inclusion of the specific solute-solvent interactions in the computational model.

\section{CONCLUSIONS}

The geometrical structures of the monomer and twelve unique dimers of 5,5-diphenylhydantoin have been investigated by DFT approach at B3LYP/6-31+G $(2 d, 2 p)$ level of theory. Calculated relative ZPE-corrected energies for the DPH dimers show that the same two dimers (2AA and $2 A B$ ) are most stable in gas-phase and in solution, as well, but an important change in relative stabilities is noted for the remaining set of 10 dimers. Almost identical geometries are predicted for the same kind of dimers in liquid phase,

Table 6. Experimental and theoretical chemical shifts (in ppm) for the most stable eight DPH dimers in DMSO

\begin{tabular}{|c|c|c|c|c|c|c|c|c|c|c|}
\hline Atoms & $\begin{array}{l}\text { Experimental } \\
\text { Data }\end{array}$ & $2 A B$ & 3AA & $2 \mathrm{AA}$ & $3 A B$ & $5 A A$ & $5 A B$ & $1 \mathrm{AA}$ & $1 \mathrm{AB}$ & $\begin{array}{c}\text { Weighted } \\
\text { average }\end{array}$ \\
\hline $\mathrm{C} 4$ & 174.81 & 173.57 & 175.81 & 173.71 & 174.72 & 173.07 & 173.41 & 178.98 & 176.4 & 174.40 \\
\hline $\mathrm{C} 2$ & 156.00 & 158.29 & 154.25 & 157.9 & 155.59 & 156.14 & 156.3 & 154.36 & 155.7 & 156.32 \\
\hline $\mathrm{C} 8, \mathrm{C} 14$ & 139.90 & 140.13 & 139.12 & 140.22 & 139.9 & 139.15 & 139.66 & 139.51 & 139.64 & 139.71 \\
\hline $\begin{array}{l}\mathrm{C} 10, \mathrm{C} 12 \\
\mathrm{C} 16, \mathrm{C} 18\end{array}$ & 128.45 & 126.41 & 126.23 & 126.75 & 126.5 & 126.61 & 126.37 & 126.15 & 126.69 & 126.46 \\
\hline $\mathrm{C} 11, \mathrm{C} 17$ & 127.98 & 126.98 & 126.74 & 126.12 & 126.23 & 126.38 & 126.53 & 126.11 & 126.33 & 126.48 \\
\hline $\begin{array}{l}\text { C9, C13, } \\
\text { C15, C19 }\end{array}$ & 126.57 & 126.62 & 125.91 & 125.43 & 126.03 & 126.66 & 126.08 & 126.1 & 125.53 & 126.11 \\
\hline $\mathrm{C} 5$ & 70.22 & 77.53 & 77.22 & 76.89 & 76.53 & 76.36 & 76.89 & 77.41 & 77.09 & 76.96 \\
\hline H31 & 11.18 & 11.65 & 11.88 & 11.59 & 11.69 & 12.15 & 9.6 & 11.94 & 9.53 & 11.50 \\
\hline $\mathrm{H} 30$ & 9.39 & 5.48 & 5.24 & 5.47 & 5.29 & 5.3 & 7.47 & 5.31 & 7.3 & 5.64 \\
\hline $\mathrm{H} 22, \mathrm{H} 27$ & 7.41 & 7.73 & 7.72 & 7.69 & 7.72 & 7.69 & 7.71 & 7.61 & 7.66 & 7.70 \\
\hline $\begin{array}{l}\mathrm{H} 20, \mathrm{H} 21, \\
\mathrm{H} 23-\mathrm{H} 26, \\
\mathrm{H} 28, \mathrm{H} 29\end{array}$ & 7.35 & 7.71 & 7.73 & 7.78 & 7.77 & 7.75 & 7.75 & 7.75 & 7.71 & 7.75 \\
\hline Population / \% & - & 15.66 & 14.41 & 14.19 & 13.93 & 11.81 & 11.63 & 5.54 & 5.50 & - \\
\hline
\end{tabular}


which, compared to the gas-phase structures show slightly longer hydrogen-bond distances. For the DPH monomer, the dihedral corresponding to the relative orientation of the two phenyl rings in solution decreases appreciable with respect to the solid state structure, concomitant with a similar increase in the dihedrals between the phenyls and hydantoin units. On the other hand, an almost quantitative agreement is observed between the calculated distances between the phenyl centroids and the two oxygens of the molecule in liquid phase and solid state.

The experimental UV-Vis and NMR spectra of DPH have been explained on the basis of the contributions due to monomers as well as Boltzmann weighted contributions of the dimers. DPH dissolved in ethanol show UV-Vis peaks between 204-205 $\mathrm{nm}$, when the concentration increases from $10^{-5} \mathrm{M}$ to $5 \cdot 10^{-5} \mathrm{M}$. The electronic transitions of $\mathrm{DPH}$ have been assigned on the basis of natural transition orbitals. All the allowed electronic excitations are dominantly driven by charge-transfer type transitions between the subunits of the molecule.

The ${ }^{1} \mathrm{H}$ and ${ }^{13} \mathrm{C}$ NMR chemical shifts of DPH in DMSO were explained by considering the Boltzmann population averaged DFT calculated data for the six dimers. The only observed discrepancy between the experimental and computed data are noted for the $\mathrm{H} 30$ proton but this deficiency can be explained by the lack of describing the specific solute-solvent interactions.

Tracking both the solid and liquid phases of DPH, the present results could help for a better understanding of the structural transformation of the molecule between the two states and for designing better formulations of this compound.

Acknowledgments. The research undertaken for this article was conducted using the Babeş-Bolyai University Research infrastructure financed by the Romanian Government through the programme PN II - Capacities - project title Integrated Network for Interdisciplinary Research - INIR and the project MADECIP (POSCEE COD SMIS CSNR 48801/1862). N. L. and V. C. highly acknowledges financial support from UEFISCDI PN-II-RU-TE-2012-3-0227 grant.

We are indebted to an anonymous reviewer of an earlier version our manuscript for providing insightful comments and suggestion for considering all the possible hydrogen-bonded dimers of phenytoin. Without the anonymous reviewers supportive work this paper would not have been possible.

Supplementary Information. Supporting information to the paper are enclosed to the electronic version of the article at: http://dx.doi.org/10.5562/cca2767.

\section{REFERENCES}

[1] A. Camerman, N. Camerman, Acta Cryst. B 1971, 27, 2205.

[2] S. Chakrabarti, R. van Severen, P. Braeckman, Pharmazie 1978, 33, 338.

[3] K. E. Tiedje, D. F. Weaver, Can. J. Neurol. Sci. 2008, 35, 232.

[4] A. Nokhodchi, N. Bolourtchian, R. Dinarvand, Int. J. Pharm. 2003, 250, 85.

[5] H. M. A. Ehmann, R. Baumgartner, D. Reischl, E. Roblegg, A. Zimmer, R. Resel, O. Werzer, Cryst. Growth Des. 2015, 15, 326.

[6] D. Reischl, C. Röthel, P. Christian, E. Roblegg, H. M. A. Ehmann, I. Salzmann, O. Werzer, Cryst. Growth Des. 2015, 15, 4687.

[7] T. Akitsu, S. Komorita, Y. Kushi, C. Li, N. Kanehisa, Y. Kai, Bull. Chem. Soc. Jpn. 1997, 70, 821.

[8] Y. Kawashima, T. Handa, H. Takeuchi, M. Okumura, H. Katou, O. Nagata, Chem. Pharm. Bull. 1986, 34, 3376.

[9] L. A. Morales, Crystal engineering of binary compounds containing pharmaceutical molecules, Master Thesis, Univ. South Florida, 2003, p. 81.

[10] R. D. B. Walsh, M. W. Bradner, S. Fleischman, L. A. Morales, B. Moulton, N. Rodriguez-Hornedo, M. J. Zaworotko, Chem. Commun. 2003, 2, 186.

[11] A. Charaf-Eddin, A. Planchat, B. Mennucci, C. Adamo, D. Jacquemin, J. Chem. Theory Comput. 2013, 9, 2749.

[12] J. C. Garro Martínez, M. F. Andrada, M. R. Estrada, G. N. Zamarbide, E. A. Castro, J. Argent. Chem. Soc. 2006, 94, 121.

[13] J. H. Poupaert, D. Vandervorst, P. Guiot, M. M. M. Moustafa, P. Dumont, J. Med. Chem. 1984, 27, 76.

[14] S. Cortes, Z. K. Liao, D. Watson, H. Kohn, J. Med. Chem. 1985, 28, 601.

[15] A. W. Roszak, D. F. Weaver, Acta Cryst. C 1998, 54, 1168.

[16] N. Naga, An investigation into the possible neuroprotective properties of phenytoin, Master Thesis, Rhodes University 2002.

[17] N. Mulsa, G. Sanghvi, P. Purohit, N. Sheth, D. Vaishnav, Inventi Rapid: Pharm. Analysis \& Quality Assurance 2013, 1, 1.

[18] A. Abbaspour, R. Mirzajani, J. Pharm. Biom. Analysis 2005, 38, 420.

[19] M. I. Walash, M. S. Rizk, Z. A. Sheribah, M. M. Salim, Chem. Cent J. 2011, 5, 85.

[20] N. Trišović, N. Valentić, G. Ušćumlić, Chem. Cent. J. 2011, 5, 62. 
[21] N. Trišović, N. Valentić, M. Erović, T. Daković-Sekulić, G. Ušćumlić, Monatsh Chem. 2011, 142, 1227.

[22] I. Tamir, R. Mchoulam, A. Y. Meyer, J. Med. Chem. 1980, 23, 220.

[23] G. M. Hannaa, Drug. Dev. Ind. Pharm. 1984, 10, 341.

[24] O. B. Ibrahim, M. M. AL-Majthoub, M. A. Mohamed, A. M. A. Adam, M. S. Refat, Int. J. Electrochem. Sci. 2015, 10, 1065.

[25] B. S. Lou, T. H. Lin, C. Z. Lo, J. Pept. Res. 2005, 66, 27.

[26] Gaussian 09, Revision C. 01, M. J. Frisch, G. W. Trucks, H. B. Schlegel, G. E. Scuseria, M. A. Robb, J. R. Cheeseman, G. Scalmani, V. Barone, B. Mennucci, G. A. Petersson, H. Nakatsuji, M. Caricato, X. Li, H. P. Hratchian, A. F. Izmaylov, J. Bloino, G. Zheng, J. L. Sonnenberg, M. Hada, M. Ehara, K. Toyota, R. Fukuda, J. Hasegawa, M. Ishida, T. Nakajima, Y. Honda, O. Kitao, H. Nakai, T. Vreven, J. A. Montgomery, Jr., J. E. Peralta, F. Ogliaro, M. Bearpark, J. J. Heyd, E. Brothers, K. N. Kudin, V. N. Staroverov, T. Keith, R. Kobayashi, J. Normand, K. Raghavachari, A. Rendell, J. C. Burant, S. S. Iyengar, J. Tomasi, M. Cossi, N. Rega, J. M. Millam, M. Klene, J. E. Knox, J. B. Cross, V. Bakken, C. Adamo, J. Jaramillo, R. Gomperts, R. E. Stratmann, O. Yazyev, A. J. Austin, R. Cammi, C. Pomelli, J. W. Ochterski, R. L. Martin, K. Morokuma, V. G. Zakrzewski, G. A. Voth, P. Salvador, J. J. Dannenberg, S. Dapprich, A. D. Daniels, O. Farkas, J. B. Foresman, J. V. Ortiz, J. Cioslowski, D. J. Fox, Gaussian, Inc., Wallingford CT, 2010.

[27] A. D. Becke, J. Chem. Phys. 1993, 98, 5648.

[28] C. Lee, W. Yang, R. G. Parr, Phys. Rev. B 1988, 37, 785.

[29] S. H. Vosko, L. Wilk, M. Nusair, Can. J. Phys. 1980, 58, 1200.

[30] P. J. Stephens, F. J. Devlin, C. F. Chabalowski, M. J. Frisch, J. Phys. Chem. 1994, 98, 11623.

[31] W. J. Hehre, R. Ditchfield, J. A. Pople, J. Chem. Phys. 1972, 56, 2257.

[32] M. J. Frisch, J. A. Pople, J. S. Binkley, J. Chem. Phys. 1984, 80, 3265.

[33] M. R. Casida, C. Jamorski, K. C. Casida, D. R. Salahub, J. Chem. Phys. 1988, 108, 4439.

[34] R. L. Martin, J. Chem. Phys. 2003, 118, 4775.

[35] A. E. Clark, J. Phys. Chem. A 2006, 110, 3790.
[36] F. Lachaud, C. Jeandon, M. Beley, R. Ruppert, P. C. Gros, A. Monari, X. Assfeld, J. Phys. Chem. A 2012, 116, 10736.

[37] G. Velmurugan, B. K. Ramamoorthi, P. Venuvanalingam, Phys. Chem. Chem. Phys. 2014, 16, 21157.

[38] T. Etienne, C. Michaux, A. Monari, X. Assfeld, E. A. Perpète, Dyes Pigm. 2014, 100, 24.

[39] S. Marković, J. Tošović, J. Phys. Chem. A 2015, 119, 9352.

[40] R. Ditchfield, Mol. Phys. 1974, 27, 789.

[41] K. Wolinski, J. F. Hilton, P. Pulay, J. Am. Chem. Soc. 1990, 112, 8251.

[42] J. Tomasi, B. Mennucci, R. Cammi, Chem. Rev. 2005, 105, 2999.

[43] G. Scalmani, M. J. Frisch, J. Chem. Phys. 2010, 132, 114110.

[44] M. Carter, V. Stephenson, D. Weaver, J. Mol. Struct. (Theochem.) 2003, 638, 57.

[45] L. Ducasse, F. Castet, A. Fritsch, I. Huc, T. Buffeteau, J. Phys. Chem. A 2007, 111, 5092.

[46] P. H. Willoughby, M. J. Jansma, T. R. Hoye, Nat. Protoc. 2014, 9, 643.

[47] A. J. Lopes Jesus, S. Jarmelo, R. Fausto, I. Reva, Spectrochim. Acta A 2015, 140, 54.

[48] A. Halasa, L. Lapinski, I. Reva, H. Rostkowska, R. Fausto, M. J. Nowak, J. Phys. Chem. A 2015, 119, 1037.

[49] T. Mori, Y. Inoue, S. Grimme, J. Org. Chem. 2006, 71, 9797.

[50] T. Buffeteau, D. Cavagnat, A. Bouchet, T. Brotin, J. Phys. Chem. A 2007, 111, 1045.

[51] M. Montejo, F. P. Ureña, G. Márquez, J. J. L. González, J. Phys. Chem. A 2008, 112, 1545.

[52] E. Vinţeler, N. -F. Stan, R. Luchian, C. Căinap, J. P. Prates-Ramalho, V. Chiş, J. Mol. Model. 2015, $21,84$.

[53] J. B. Foresman, $\mathbb{E}$. Frisch, Exploring Chemistry with Electronic Structure Methods (third edition), Gaussian Inc., Wallingford, CT USA, 2015.

[54] X. Zheng, Q. Peng, J. Lin, Y. Wang, J. Zhou, Y. Jiao, Y. Bai, Y. Huang, F. Li, X. Liu, X. Pua, Z. Lu, J. Mater. Chem. C 2015, 3, 6970.

[55] Gaussian Tech Notes. Plotting UV/Vis Spectra from Oscillator \& Dipole Strengths.

[56] P. J. Stephens, N. Harada, Chirality 2010, 22, 229. 
Molecular structure of phenytoin:

NMR, UV-Vis and quantum chemical calculations

Raluca Luchian ${ }^{1}$, Emil Vinţeler ${ }^{1}$, Cosmina Chiş ${ }^{2}$, Mihai Vasilescu ${ }^{1}$, Nicolae Leopold ${ }^{1}$, Vasile Chiş $^{1} *$

${ }^{1}$ Babeş-Bolyai University, Faculty of Physics,1 Kogălniceanu, RO-400084 Cluj-Napoca, Romania ${ }^{2}$ Iuliu Haţieganu University of Medicine and Pharmacy, 8 Victor Babeş, RO-400012 Cluj-Napoca, Romania

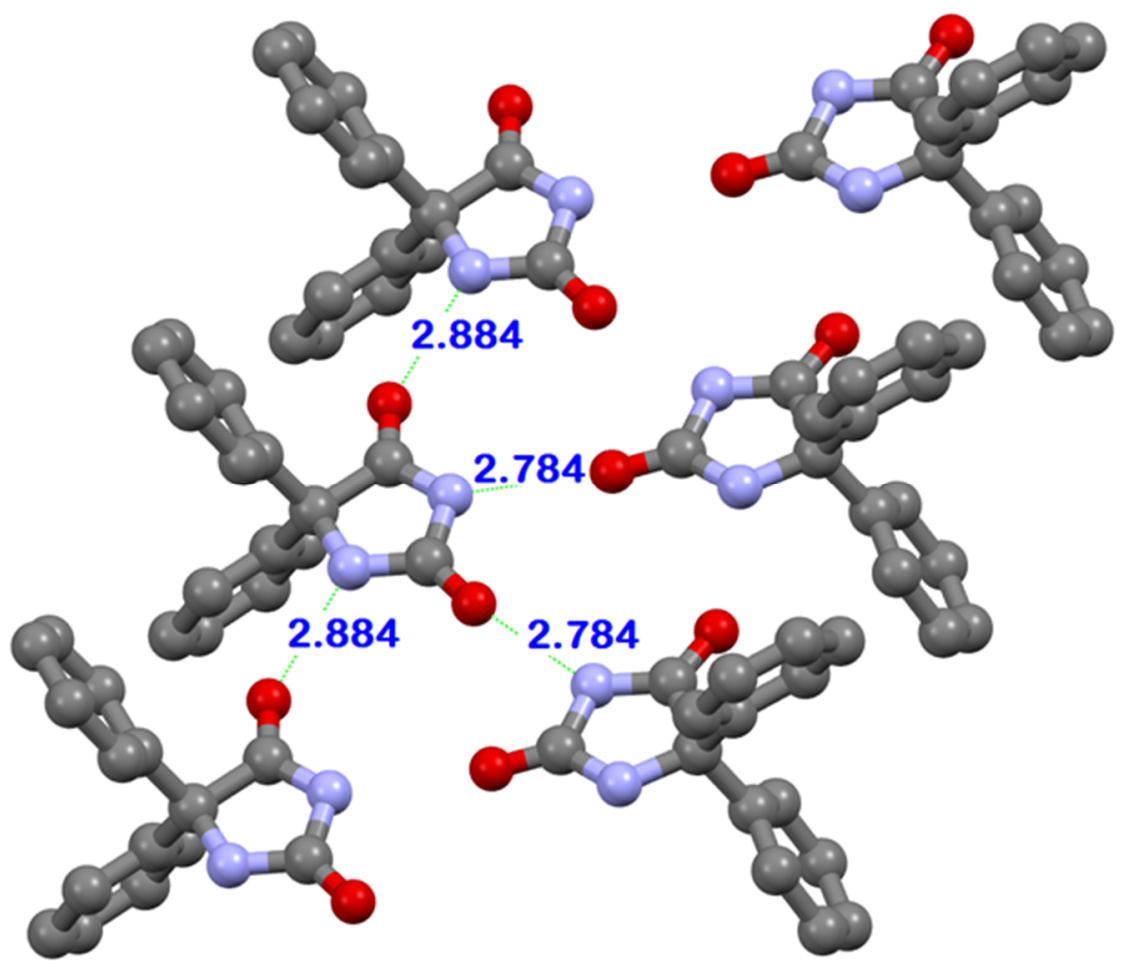

Fig.S1 Intermolecular hydrogen bonding pattern in DPH single crystals (data from ref. [1]). Hydrogen atoms have been removed for the sake of clarity.

\footnotetext{
* *Tel.: +40264405300; fax: +40264191906
}

E-mail address: vasile.chis@phys.ubbcluj.ro (V. Chiș). 
Table S1 Theoretical UV-Vis absorption spectral data calculated for DPH dimers in ethanol, with populations greater than $5 \%$ (data for $2 \mathrm{AB}$ dimer are given in Table 4)

\begin{tabular}{|c|c|c|c|c|c|}
\hline Dimer & Excited state & $\lambda(\mathrm{nm})$ & $\mathrm{f}^{\mathrm{a})}$ & transitions $\mathrm{s}^{\mathrm{b})}$ & Contributions $\left.(\%)^{\mathrm{c}}\right)$ \\
\hline \multirow{8}{*}{$2 \mathrm{AA}$} & \multirow{2}{*}{ S1 } & \multirow{2}{*}{247.9} & \multirow{2}{*}{0.054} & $\mathrm{H}-1 \rightarrow \mathrm{L}$ & 28 \\
\hline & & & & $\mathrm{H} \rightarrow \mathrm{L}+1$ & 22 \\
\hline & \multirow[t]{2}{*}{ S2 } & \multirow{2}{*}{247.6} & \multirow{2}{*}{0.081} & $\mathrm{H}-1 \rightarrow \mathrm{L}+1$ & 22 \\
\hline & & & & $\mathrm{H} \rightarrow \mathrm{L}$ & 28 \\
\hline & S22 & 216.0 & 0.106 & $\mathrm{H}-3 \rightarrow \mathrm{L}+2$ & 13 \\
\hline & S40 & 207.6 & 0.295 & $\mathrm{H} \rightarrow \mathrm{L}+9$ & 11 \\
\hline & S45 & 204.4 & 0.112 & $\mathrm{H} \rightarrow \mathrm{L}+8$ & 12 \\
\hline & S46 & 204.2 & 0.062 & $\mathrm{H}-5 \rightarrow \mathrm{L}+7$ & 20 \\
\hline \multirow{11}{*}{$3 \mathrm{AA}$} & \multirow[t]{2}{*}{ S1 } & \multirow{2}{*}{247.9} & \multirow{2}{*}{0.057} & $\mathrm{H}-1 \rightarrow \mathrm{L}$ & 51 \\
\hline & & & & $\mathrm{H} \rightarrow \mathrm{L}$ & 35 \\
\hline & \multirow[t]{2}{*}{ S2 } & \multirow{2}{*}{247.8} & \multirow{2}{*}{0.065} & $\mathrm{H} \rightarrow \mathrm{L}+1$ & 32 \\
\hline & & & & $\mathrm{H}-2 \rightarrow \mathrm{L}+1$ & 18 \\
\hline & \multirow[t]{2}{*}{ S15 } & \multirow{2}{*}{224.3} & \multirow{2}{*}{0.047} & $\mathrm{H} \rightarrow \mathrm{L}+3$ & 43 \\
\hline & & & & $\mathrm{H}-1 \rightarrow \mathrm{L}+2$ & 18 \\
\hline & \multirow[t]{2}{*}{ S24 } & \multirow{2}{*}{215.6} & \multirow{2}{*}{0.055} & $\mathrm{H}-2 \rightarrow \mathrm{L}+3$ & 22 \\
\hline & & & & $\mathrm{H}-2 \rightarrow \mathrm{L}+5$ & 17 \\
\hline & S37 & 210.1 & 0.065 & $\mathrm{H}-10 \rightarrow \mathrm{L}$ & 17 \\
\hline & S41 & 207.7 & 0.197 & $\mathrm{H}-2 \rightarrow \mathrm{L}+5$ & 15 \\
\hline & S47 & 204.0 & 0.062 & $\mathrm{H}-5 \rightarrow \mathrm{L}+7$ & 20 \\
\hline \multirow{11}{*}{$3 \mathrm{AB}$} & \multirow[t]{2}{*}{ S1 } & \multirow{2}{*}{248.3} & 0046 & $\mathrm{H} \rightarrow \mathrm{L}+1$ & 23 \\
\hline & & & 0.046 & $\mathrm{H} \rightarrow \mathrm{L}$ & 20 \\
\hline & S2 & 2477 & 0070 & $\mathrm{H}-1 \rightarrow \mathrm{L}$ & 51 \\
\hline & & 247.7 & 0.079 & $\mathrm{H} \rightarrow \mathrm{L}+1$ & 20 \\
\hline & S24 & 216.0 & 0.048 & $\mathrm{H}-2 \rightarrow \mathrm{L}+3$ & 25 \\
\hline & S34 & 211.1 & 0.047 & $\mathrm{H} \rightarrow \mathrm{L}+4$ & 18 \\
\hline & S37 & & & $\mathrm{H}-11 \rightarrow \mathrm{L}$ & 18 \\
\hline & & 210.1 & 0.048 & $\mathrm{H}-10 \rightarrow \mathrm{L}$ & 17 \\
\hline & S44 & 205.1 & 0.069 & $\mathrm{H}-6 \rightarrow \mathrm{L}+4$ & 16 \\
\hline & S46 & 204.7 & 0.049 & $\mathrm{H}-9 \rightarrow \mathrm{L}$ & 44 \\
\hline & S47 & 204.0 & 0.046 & $\mathrm{H}-9 \rightarrow \mathrm{L}$ & 15 \\
\hline & S1 & 2484 & 0071 & $\mathrm{H}-1 \rightarrow \mathrm{L}$ & 30 \\
\hline & & 248.4 & 0.071 & $\mathrm{H} \rightarrow \mathrm{L}+1$ & 30 \\
\hline & S2 & & & $\mathrm{H} \rightarrow \mathrm{L}+1$ & 28 \\
\hline & & 247.6 & 0.058 & $\mathrm{H}-1 \rightarrow \mathrm{L}+1$ & 19 \\
\hline & & & & $\mathrm{H}-2 \rightarrow \mathrm{L}+1$ & 19 \\
\hline & S15 & & & $\mathrm{H}-7 \rightarrow \mathrm{L}+1$ & 27 \\
\hline & & 224.6 & 0.040 & $\mathrm{H} \rightarrow \mathrm{L}+2$ & 26 \\
\hline $5 \Delta \mathrm{A}$ & & & & $\mathrm{H}-1 \rightarrow \mathrm{L}+2$ & 17 \\
\hline $5 \mathrm{AA}$ & S23 & & & $\mathrm{H}-2 \rightarrow \mathrm{L}+2$ & 25 \\
\hline & & 216.2 & 0.048 & $\mathrm{H}-2 \rightarrow \mathrm{L}+4$ & 20 \\
\hline & S24 & 2156 & (2047 & $\mathrm{H}-3 \rightarrow \mathrm{L}+3$ & 32 \\
\hline & & 215.6 & 0.042 & $\mathrm{H}-3 \rightarrow \mathrm{L}+5$ & 19 \\
\hline & S40 & 207.8 & 0.093 & $\mathrm{H}-3 \rightarrow \mathrm{L}+5$ & 15 \\
\hline & S41 & 207.7 & 0.200 & $\mathrm{H}-2 \rightarrow \mathrm{L}+4$ & 14 \\
\hline & S42 & 207.3 & 0.069 & $\mathrm{H}-2 \rightarrow \mathrm{L}+9$ & 15 \\
\hline & S45 & 205.3 & 0.074 & $\mathrm{H}-6 \rightarrow \mathrm{L}+5$ & 25 \\
\hline
\end{tabular}


Electronic Supplementary Information

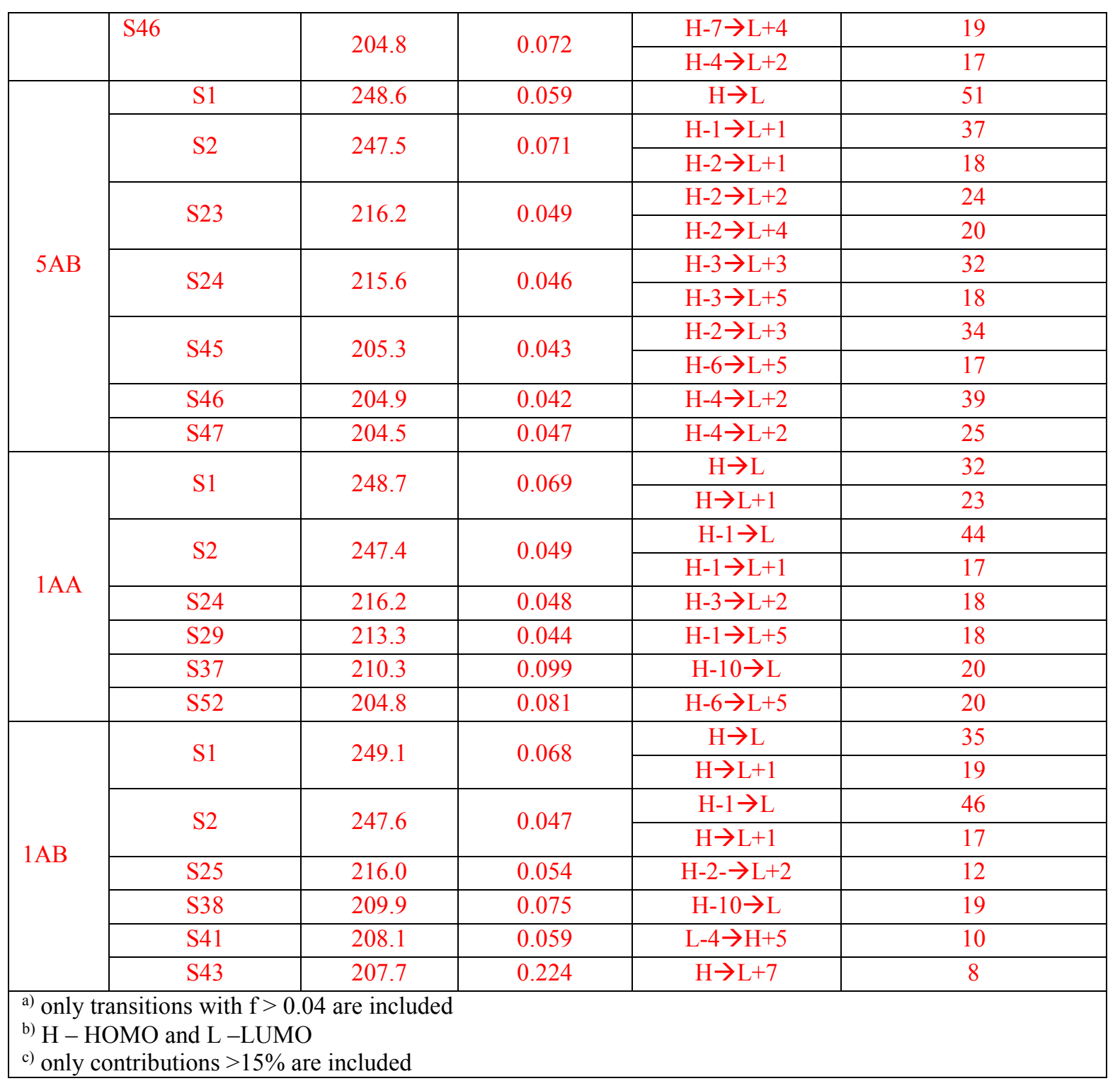


Table S2 Cartesian coordinates of the optimized structures of the monomer and the twelve dimers of 5,5diphenylhydantoin in gas-phase at B3LYP/6-31+G(2d,2p) level of theory

\begin{tabular}{|c|c|c|c|c|c|c|c|}
\hline \multicolumn{4}{|c|}{ Monomer } & & & & \\
\hline $\mathrm{N}$ & -0.1212 & 1.4452 & -1.085 & & & & \\
\hline C & -0.313 & 2.7205 & \multicolumn{2}{|l|}{-0.6213} & & & \\
\hline $\mathrm{N}$ & -0.167 & 2.6438 & \multicolumn{2}{|l|}{0.7745} & & & \\
\hline $\mathrm{C}$ & -0.0293 & 1.3597 & \multicolumn{2}{|l|}{1.2411} & & & \\
\hline $\mathrm{C}$ & -0.0131 & 0.4391 & \multicolumn{2}{|l|}{-0.0189} & & & \\
\hline 0 & -0.5525 & 3.7235 & \multicolumn{2}{|l|}{-1.2538} & & & \\
\hline 0 & 0.0664 & 1.0175 & \multicolumn{2}{|l|}{2.3945} & & & \\
\hline $\mathrm{C}$ & -1.2211 & -0.507 & \multicolumn{2}{|l|}{-0.0678} & & & \\
\hline C & -2.3317 & -0.3484 & \multicolumn{2}{|l|}{0.7667} & & & \\
\hline $\mathrm{C}$ & -3.4475 & -1.1751 & \multicolumn{2}{|l|}{0.6243} & & & \\
\hline $\mathrm{C}$ & -3.4696 & -2.1662 & \multicolumn{2}{|l|}{-0.3549} & & & \\
\hline C & -2.3636 & -2.3332 & \multicolumn{2}{|l|}{-1.1896} & & & \\
\hline $\mathrm{C}$ & -1.2467 & -1.5135 & \multicolumn{2}{|l|}{-1.0427} & & & \\
\hline $\mathrm{C}$ & 1.3259 & -0.3107 & \multicolumn{2}{|l|}{-0.0471} & & & \\
\hline C & 2.3441 & 0.0428 & \multicolumn{2}{|l|}{-0.9355} & & & \\
\hline C & 3.5629 & -0.6401 & \multicolumn{2}{|l|}{-0.9218} & & & \\
\hline $\mathrm{C}$ & 3.7781 & -1.6734 & \multicolumn{2}{|l|}{-0.0128} & & & \\
\hline C & 2.767 & -2.0223 & 0.8852 & & & & \\
\hline $\mathrm{C}$ & 1.5489 & -1.3481 & 0.868 & & & & \\
\hline $\mathrm{H}$ & -2.3308 & 0.4053 & 1.544 & & & & \\
\hline $\mathrm{H}$ & -4.2969 & -1.0424 & 1.2846 & & & & \\
\hline $\mathrm{H}$ & -4.3369 & -2.8074 & -0.4634 & & & & \\
\hline $\mathrm{H}$ & -2.3654 & -3.1062 & -1.9498 & & & & \\
\hline $\mathrm{H}$ & -0.3841 & -1.666 & -1.6821 & & & & \\
\hline $\mathrm{H}$ & 2.1891 & 0.8529 & -1.6368 & & & & \\
\hline $\mathrm{H}$ & 4.3412 & -0.3579 & -1.6218 & & & & \\
\hline $\mathrm{H}$ & 4.7243 & -2.2023 & -0.0011 & & & & \\
\hline $\mathrm{H}$ & 2.9262 & -2.8209 & 1.6008 & & & & \\
\hline $\mathrm{H}$ & 0.772 & -1.6218 & 1.5709 & & & & \\
\hline $\mathrm{H}$ & -0.472 & 1.2114 & -2.001 & & & & \\
\hline $\mathrm{H}$ & -0.2089 & 3.4595 & 1.367 & & & & \\
\hline Dim & & & & & & & \\
\hline $1 \mathrm{AA}$ & & & & $1 \mathrm{AB}$ & & & \\
\hline C & -3.720 & -1.143 & -0.338 & C & -3.807 & -1.156 & -0.4248 \\
\hline C & -2.939 & -2.294 & -0.479 & C & -3.122 & -2.360 & -0.6157 \\
\hline C & -3.454 & -3.426 & -1.115 & C & -3.718 & -3.410 & -1.3162 \\
\hline $\mathrm{C}$ & -4.756 & -3.423 & -1.612 & C & -5.006 & -3.273 & -1.8306 \\
\hline C & -5.541 & -2.277 & -1.478 & C & -5.696 & -2.074 & -1.6458 \\
\hline $\mathrm{C}$ & -5.025 & -1.145 & -0.851 & C & -5.098 & -1.023 & -0.9532 \\
\hline C & -3.483 & 1.401 & -0.331 & C & -3.396 & 1.361 & -0.2524 \\
\hline $\mathrm{C}$ & -4.046 & 2.517 & 0.294 & C & -3.878 & 2.468 & 0.4503 \\
\hline C & -4.228 & 3.707 & -0.413 & C & -3.984 & 3.712 & -0.1757 \\
\hline C & -3.839 & 3.797 & -1.748 & C & -3.600 & 3.864 & -1.5062 \\
\hline C & -3.266 & 2.688 & -2.374 & C & -3.108 & 2.762 & -2.2099 \\
\hline C & -3.090 & 1.498 & -1.672 & C & -3.006 & 1.520 & -1.5889 \\
\hline $\mathrm{H}$ & -1.921 & -2.316 & -0.111 & $\mathrm{H}$ & -2.117 & -2.486 & -0.2341 \\
\hline $\mathrm{H}$ & -2.833 & -4.308 & -1.219 & $\mathrm{H}$ & -3.170 & -4.334 & -1.4585 \\
\hline $\mathrm{H}$ & -5.154 & -4.303 & -2.105 & $\mathrm{H}$ & -5.467 & -4.090 & -2.3741 \\
\hline $\mathrm{H}$ & -6.553 & -2.260 & -1.867 & $\mathrm{H}$ & -6.696 & -1.952 & -2.0459 \\
\hline $\mathrm{H}$ & -5.636 & -0.253 & -0.771 & $\mathrm{H}$ & -5.636 & -0.089 & -0.8335 \\
\hline $\mathrm{H}$ & -4.341 & 2.456 & 1.334 & $\mathrm{H}$ & -4.170 & 2.359 & 1.4871 \\
\hline
\end{tabular}




\begin{tabular}{|c|c|c|c|c|c|c|c|}
\hline $\mathrm{H}$ & -4.672 & 4.562 & 0.085 & $\mathrm{H}$ & -4.365 & 4.560 & 0.3821 \\
\hline $\mathrm{H}$ & -3.979 & 4.721 & -2.297 & $\mathrm{H}$ & -3.683 & 4.829 & -1.9925 \\
\hline $\mathrm{H}$ & -2.957 & 2.748 & -3.411 & $\mathrm{H}$ & -2.805 & 2.869 & -3.2455 \\
\hline $\mathrm{H}$ & -2.645 & 0.643 & -2.165 & $\mathrm{H}$ & -2.624 & 0.672 & -2.1426 \\
\hline $\mathrm{C}$ & -2.903 & -0.086 & 2.780 & $\mathrm{C}$ & -2.904 & -0.384 & 2.744 \\
\hline $\mathrm{C}$ & -1.729 & 0.017 & 0.803 & $\mathrm{C}$ & -1.734 & -0.214 & 0.7683 \\
\hline 0 & -0.803 & 0.028 & 0.008 & 0 & -0.812 & -0.202 & -0.0308 \\
\hline 0 & -3.109 & -0.246 & 3.960 & 0 & -3.115 & -0.618 & 3.9097 \\
\hline $\mathrm{N}$ & -3.827 & 0.106 & 1.780 & $\mathrm{~N}$ & -3.815 & -0.046 & 1.7714 \\
\hline $\mathrm{H}$ & -4.774 & -0.197 & 1.945 & $\mathrm{H}$ & -4.782 & -0.292 & 1.923 \\
\hline $\mathrm{N}$ & -1.642 & -0.052 & 2.155 & $\mathrm{~N}$ & -1.646 & -0.395 & 2.1106 \\
\hline $\mathrm{H}$ & -0.745 & -0.095 & 2.661 & $\mathrm{H}$ & -0.753 & -0.543 & 2.6028 \\
\hline $\mathrm{C}$ & -3.239 & 0.092 & 0.436 & $\mathrm{C}$ & -3.238 & -0.009 & 0.423 \\
\hline $\mathrm{C}$ & 3.298 & -1.330 & -0.495 & $\mathrm{C}$ & 3.275 & 1.301 & -0.1968 \\
\hline $\mathrm{C}$ & 4.079 & -2.449 & -0.195 & C & 4.165 & 2.286 & 0.2354 \\
\hline $\mathrm{C}$ & 4.059 & -3.569 & -1.030 & C & 4.143 & 3.559 & -0.3416 \\
\hline $\mathrm{C}$ & 3.259 & -3.584 & -2.169 & C & 3.234 & 3.860 & -1.352 \\
\hline $\mathrm{C}$ & 2.477 & -2.468 & -2.476 & C & 2.343 & 2.878 & -1.7897 \\
\hline $\mathrm{C}$ & 2.500 & -1.350 & -1.647 & C & 2.366 & 1.609 & -1.2195 \\
\hline $\mathrm{C}$ & 3.618 & 1.193 & -0.346 & C & 3.636 & -1.188 & -0.6107 \\
\hline $\mathrm{C}$ & 2.818 & 2.337 & -0.307 & C & 2.910 & -2.374 & -0.7526 \\
\hline $\mathrm{C}$ & 3.207 & 3.495 & -0.985 & $\mathrm{C}$ & 3.325 & -3.352 & -1.6587 \\
\hline $\mathrm{C}$ & 4.403 & 3.523 & -1.697 & $\mathrm{C}$ & 4.473 & -3.159 & -2.4235 \\
\hline $\mathrm{C}$ & 5.211 & 2.384 & -1.731 & C & 5.206 & -1.979 & -2.2788 \\
\hline $\mathrm{C}$ & 4.820 & 1.226 & -1.064 & C & 4.790 & -0.999 & -1.3813 \\
\hline $\mathrm{H}$ & 4.722 & -2.452 & 0.676 & $\mathrm{H}$ & 4.891 & 2.068 & 1.0078 \\
\hline $\mathrm{H}$ & 4.675 & -4.426 & -0.785 & $\mathrm{H}$ & 4.843 & 4.312 & 0.0046 \\
\hline $\mathrm{H}$ & 3.245 & -4.454 & -2.817 & $\mathrm{H}$ & 3.218 & 4.849 & -1.7968 \\
\hline $\mathrm{H}$ & 1.852 & -2.466 & -3.362 & $\mathrm{H}$ & 1.630 & 3.098 & -2.5762 \\
\hline $\mathrm{H}$ & 1.895 & -0.486 & -1.902 & $\mathrm{H}$ & 1.672 & 0.855 & -1.5745 \\
\hline $\mathrm{H}$ & 1.888 & 2.331 & 0.247 & $\mathrm{H}$ & 2.020 & -2.537 & -0.1589 \\
\hline $\mathrm{H}$ & 2.570 & 4.372 & -0.951 & $\mathrm{H}$ & 2.748 & -4.264 & -1.7618 \\
\hline $\mathrm{H}$ & 4.706 & 4.423 & -2.221 & $\mathrm{H}$ & 4.796 & -3.919 & -3.1262 \\
\hline $\mathrm{H}$ & 6.146 & 2.396 & -2.280 & $\mathrm{H}$ & 6.103 & -1.820 & -2.8667 \\
\hline $\mathrm{H}$ & 5.453 & 0.348 & -1.095 & $\mathrm{H}$ & 5.364 & -0.088 & -1.2765 \\
\hline $\mathrm{C}$ & 1.943 & -0.111 & 2.385 & $\mathrm{C}$ & 1.933 & -0.550 & 2.3334 \\
\hline $\mathrm{C}$ & 4.139 & -0.215 & 1.668 & C & 4.129 & -0.257 & 1.6695 \\
\hline 0 & 5.343 & -0.296 & 1.701 & 0 & 5.332 & -0.176 & 1.7256 \\
\hline 0 & 1.008 & -0.131 & 3.175 & 0 & 0.996 & -0.722 & 3.1021 \\
\hline $\mathrm{N}$ & 1.910 & 0.004 & 1.040 & $\mathrm{~N}$ & 1.906 & -0.367 & 0.996 \\
\hline $\mathrm{H}$ & 1.018 & -0.020 & 0.542 & $\mathrm{H}$ & 1.013 & -0.257 & 0.5112 \\
\hline $\mathrm{N}$ & 3.290 & -0.208 & 2.750 & $\mathrm{~N}$ & 3.277 & -0.513 & 2.7193 \\
\hline $\mathrm{H}$ & 3.591 & -0.268 & 3.711 & $\mathrm{H}$ & 3.576 & -0.660 & 3.6718 \\
\hline $\mathrm{C}$ & 3.230 & -0.087 & 0.408 & $\mathrm{C}$ & 3.223 & -0.113 & 0.4073 \\
\hline $2 \mathrm{AA}$ & & & & $2 \mathrm{AB}$ & & & \\
\hline $\mathrm{C}$ & 0.2537 & 4.8667 & 1.2538 & C & -4.8623 & -1.3028 & 0.0724 \\
\hline $\mathrm{C}$ & -0.4587 & 4.5763 & 2.4209 & $\mathrm{C}$ & -4.5099 & -2.3905 & -0.7326 \\
\hline
\end{tabular}




\begin{tabular}{|c|c|c|c|c|c|c|c|}
\hline C & -0.2145 & 5.2929 & 3.5945 & $\mathrm{C}$ & -5.2164 & -3.5915 & -0.6476 \\
\hline C & 0.7445 & 6.3032 & 3.6176 & $\mathrm{C}$ & -6.2794 & -3.7222 & 0.244 \\
\hline C & 1.4574 & 6.6015 & 2.455 & $\mathrm{C}$ & -6.6393 & -2.6402 & 1.0486 \\
\hline C & 1.2091 & 5.8921 & 1.2824 & $\mathrm{C}$ & -5.9392 & -1.4389 & 0.9589 \\
\hline C & -0.1168 & 4.9499 & -1.2701 & $\mathrm{C}$ & -4.9498 & 1.2495 & 0.0483 \\
\hline C & 0.6173 & 4.7612 & -2.4437 & $\mathrm{C}$ & -4.8011 & 2.2866 & 0.9722 \\
\hline C & 0.3873 & 5.5694 & -3.5597 & $\mathrm{C}$ & -5.6136 & 3.4207 & 0.9006 \\
\hline C & -0.5859 & 6.5651 & -3.5164 & C & -6.5742 & 3.5331 & -0.1017 \\
\hline C & -1.33 & 6.7499 & -2.3492 & $\mathrm{C}$ & -6.719 & 2.5036 & -1.0345 \\
\hline C & -1.0969 & 5.9504 & -1.2334 & $\mathrm{C}$ & -5.9155 & 1.3691 & -0.96 \\
\hline $\mathrm{H}$ & -1.2205 & 3.8072 & 2.4213 & $\mathrm{H}$ & -3.6974 & -2.3061 & -1.4431 \\
\hline $\mathrm{H}$ & -0.7807 & 5.0585 & 4.4888 & $\mathrm{H}$ & -4.9337 & -4.4221 & -1.2842 \\
\hline $\mathrm{H}$ & 0.9315 & 6.8582 & 4.5298 & $\mathrm{H}$ & -6.8272 & -4.6555 & 0.3077 \\
\hline $\mathrm{H}$ & 2.2 & 7.3913 & 2.4577 & $\mathrm{H}$ & -7.4699 & -2.7268 & 1.74 \\
\hline $\mathrm{H}$ & 1.7514 & 6.1483 & 0.3784 & $\mathrm{H}$ & -6.2418 & -0.5974 & 1.5724 \\
\hline $\mathrm{H}$ & 1.3671 & 3.9817 & -2.4909 & $\mathrm{H}$ & -4.0494 & 2.2138 & 1.748 \\
\hline $\mathrm{H}$ & 0.9695 & 5.4137 & -4.461 & $\mathrm{H}$ & -5.4889 & 4.2142 & 1.6288 \\
\hline $\mathrm{H}$ & -0.7658 & 7.1911 & -4.383 & $\mathrm{H}$ & -7.2037 & 4.4138 & -0.1591 \\
\hline $\mathrm{H}$ & -2.0939 & 7.5179 & -2.3065 & $\mathrm{H}$ & -7.4589 & 2.5837 & -1.8229 \\
\hline $\mathrm{H}$ & -1.6818 & 6.097 & -0.3341 & $\mathrm{H}$ & -6.0306 & 0.578 & -1.6903 \\
\hline C & 0.846 & 1.8195 & -0.1001 & $\mathrm{C}$ & -1.8198 & -0.0324 & 0.8484 \\
\hline C & -1.0965 & 3.0409 & 0.0363 & C & -3.038 & 0.088 & -1.0971 \\
\hline o & -2.2679 & 3.3114 & 0.1331 & 0 & -3.3062 & 0.1405 & -2.2717 \\
\hline O & 1.592 & 0.8497 & -0.0788 & 0 & -0.8506 & -0.1516 & 1.5859 \\
\hline $\mathrm{N}$ & 1.2154 & 3.1283 & -0.1966 & $\mathrm{~N}$ & -3.1294 & 0.0069 & 1.2255 \\
\hline $\mathrm{H}$ & 2.164 & 3.3855 & 0.028 & $\mathrm{H}$ & -3.3867 & -0.3498 & 2.1328 \\
\hline $\mathrm{N}$ & -0.5412 & 1.785 & -0.0355 & $\mathrm{~N}$ & -1.7832 & 0.0952 & -0.5344 \\
\hline $\mathrm{H}$ & -1.0582 & 0.8947 & -0.0299 & $\mathrm{H}$ & -0.8919 & 0.1379 & -1.0482 \\
\hline C & 0.0887 & 4.0572 & -0.0399 & C & -4.0565 & 0.0035 & 0.0862 \\
\hline C & -0.2537 & -4.8667 & 1.2538 & C & 4.8623 & 1.3028 & -0.0724 \\
\hline C & 0.4587 & -4.5763 & 2.4209 & C & 4.5099 & 2.3905 & 0.7326 \\
\hline C & 0.2145 & -5.2929 & 3.5945 & C & 5.2164 & 3.5915 & 0.6476 \\
\hline C & -0.7445 & -6.3032 & 3.6176 & C & 6.2794 & 3.7222 & -0.244 \\
\hline C & -1.4574 & -6.6015 & 2.455 & C & 6.6393 & 2.6402 & -1.0486 \\
\hline C & -1.2091 & -5.8921 & 1.2824 & C & 5.9392 & 1.4389 & -0.9589 \\
\hline C & 0.1168 & -4.9499 & -1.2701 & C & 4.9498 & -1.2495 & -0.0483 \\
\hline C & -0.6173 & -4.7612 & -2.4437 & C & 4.8011 & -2.2866 & -0.9722 \\
\hline C & -0.3873 & -5.5694 & -3.5597 & C & 5.6136 & -3.4207 & -0.9006 \\
\hline C & 0.5859 & -6.5651 & -3.5164 & C & 6.5742 & -3.5331 & 0.1017 \\
\hline C & 1.33 & -6.7499 & -2.3492 & C & 6.719 & -2.5036 & 1.0345 \\
\hline C & 1.0969 & -5.9504 & -1.2334 & C & 5.9155 & -1.3691 & 0.96 \\
\hline $\mathrm{H}$ & 1.2205 & -3.8072 & 2.4213 & $\mathrm{H}$ & 3.6974 & 2.3061 & 1.4431 \\
\hline $\mathrm{H}$ & 0.7807 & -5.0585 & 4.4888 & $\mathrm{H}$ & 4.9337 & 4.4221 & 1.2842 \\
\hline $\mathrm{H}$ & -0.9315 & -6.8582 & 4.5298 & $\mathrm{H}$ & 6.8272 & 4.6555 & -0.3077 \\
\hline $\mathrm{H}$ & -2.2 & -7.3913 & 2.4577 & $\mathrm{H}$ & 7.4699 & 2.7268 & -1.74 \\
\hline $\mathrm{H}$ & -1.7514 & -6.1483 & 0.3784 & $\mathrm{H}$ & 6.2418 & 0.5974 & -1.5724 \\
\hline $\mathrm{H}$ & -1.3671 & -3.9817 & -2.4909 & $\mathrm{H}$ & 4.0494 & -2.2138 & -1.748 \\
\hline $\mathrm{H}$ & -0.9695 & -5.4137 & -4.461 & $\mathrm{H}$ & 5.4889 & -4.2142 & -1.6288 \\
\hline
\end{tabular}




\begin{tabular}{|c|c|c|c|c|c|c|c|}
\hline $\mathrm{H}$ & 0.7658 & -7.1911 & -4.383 & $\mathrm{H}$ & 7.2037 & -4.4138 & 0.1591 \\
\hline $\mathrm{H}$ & 2.0939 & -7.5179 & -2.3065 & $\mathrm{H}$ & 7.4589 & -2.5837 & 1.8229 \\
\hline $\mathrm{H}$ & 1.6818 & -6.097 & -0.3341 & $\mathrm{H}$ & 6.0306 & -0.578 & 1.6903 \\
\hline $\mathrm{C}$ & -0.846 & -1.8195 & -0.1001 & C & 1.8198 & 0.0324 & -0.8484 \\
\hline $\mathrm{C}$ & 1.0965 & -3.0409 & 0.0363 & C & 3.038 & -0.088 & 1.0971 \\
\hline 0 & 2.2679 & -3.3114 & 0.1331 & o & 3.3062 & -0.1405 & 2.2717 \\
\hline 0 & -1.592 & -0.8497 & -0.0788 & 0 & 0.8506 & 0.1516 & -1.5859 \\
\hline $\mathrm{N}$ & -1.2154 & -3.1283 & -0.1966 & $\mathrm{~N}$ & 3.1294 & -0.0069 & -1.2255 \\
\hline $\mathrm{H}$ & -2.164 & -3.3855 & 0.028 & $\mathrm{H}$ & 3.3867 & 0.3498 & -2.1328 \\
\hline $\mathrm{N}$ & 0.5412 & -1.785 & -0.0355 & $\mathrm{~N}$ & 1.7832 & -0.0952 & 0.5344 \\
\hline $\mathrm{H}$ & 1.0582 & -0.8947 & -0.0299 & $\mathrm{H}$ & 0.8919 & -0.1379 & 1.0482 \\
\hline $\mathrm{C}$ & -0.0887 & -4.0572 & -0.0399 & $\mathrm{C}$ & 4.0565 & -0.0035 & -0.0862 \\
\hline $3 \mathrm{AA}$ & & & & $3 A B$ & & & \\
\hline $\mathrm{C}$ & -4.4534 & -1.226 & -0.1505 & C & -4.4352 & -1.1957 & -0.3299 \\
\hline $\mathrm{C}$ & -3.7095 & -2.3989 & -0.3108 & C & -3.6895 & -2.3519 & -0.5817 \\
\hline $\mathrm{C}$ & -4.3228 & -3.571 & -0.7569 & C & -4.2828 & -3.4599 & -1.1879 \\
\hline $\mathrm{C}$ & -5.6864 & -3.5874 & -1.043 & C & -5.6295 & -3.4294 & -1.5458 \\
\hline $\mathrm{C}$ & -6.436 & -2.4207 & -0.8865 & C & -6.3807 & -2.2799 & -1.2984 \\
\hline $\mathrm{C}$ & -5.8226 & -1.2488 & -0.4488 & C & -5.7864 & -1.1707 & -0.6995 \\
\hline $\mathrm{C}$ & -4.2426 & 1.3098 & -0.3775 & C & -4.2607 & 1.3513 & -0.1831 \\
\hline $\mathrm{C}$ & -4.7388 & 2.4545 & 0.2507 & C & -4.8007 & 2.3739 & 0.6004 \\
\hline $\mathrm{C}$ & -5.0685 & 3.586 & -0.4993 & C & -5.1484 & 3.598 & 0.0239 \\
\hline $\mathrm{C}$ & -4.8945 & 3.5873 & -1.8813 & C & -4.9483 & 3.8148 & -1.3374 \\
\hline $\mathrm{C}$ & -4.388 & 2.449 & -2.5124 & C & -4.3979 & 2.7992 & -2.1226 \\
\hline $\mathrm{C}$ & -4.0658 & 1.3177 & -1.7674 & C & -4.0583 & 1.5758 & -1.5514 \\
\hline $\mathrm{H}$ & -2.6464 & -2.4077 & -0.106 & $\mathrm{H}$ & -2.6396 & -2.3959 & -0.3201 \\
\hline $\mathrm{H}$ & -3.7287 & -4.4691 & -0.8818 & $\mathrm{H}$ & -3.6873 & -4.3449 & -1.3813 \\
\hline $\mathrm{H}$ & -6.1605 & -4.4984 & -1.39 & $\mathrm{H}$ & -6.0886 & -4.2905 & -2.0178 \\
\hline $\mathrm{H}$ & -7.4963 & -2.419 & -1.1124 & $\mathrm{H}$ & -7.4275 & -2.2417 & -1.5776 \\
\hline $\mathrm{H}$ & -6.41 & -0.3424 & -0.3517 & $\mathrm{H}$ & -6.3746 & -0.2758 & -0.5302 \\
\hline $\mathrm{H}$ & -4.866 & 2.4646 & 1.3258 & $\mathrm{H}$ & -4.9481 & 2.2171 & 1.6614 \\
\hline $\mathrm{H}$ & -5.4582 & 4.4645 & 0.0027 & $\mathrm{H}$ & -5.5718 & 4.3796 & 0.6447 \\
\hline $\mathrm{H}$ & -5.1492 & 4.4659 & -2.4633 & $\mathrm{H}$ & -5.216 & 4.7655 & -1.7845 \\
\hline $\mathrm{H}$ & -4.2435 & 2.4407 & -3.5868 & $\mathrm{H}$ & -4.232 & 2.9592 & -3.1819 \\
\hline $\mathrm{H}$ & -3.6707 & 0.4407 & -2.2648 & $\mathrm{H}$ & -3.6291 & 0.7951 & -2.1668 \\
\hline $\mathrm{C}$ & -3.0766 & 0.0563 & 2.6724 & C & -3.0769 & -0.321 & 2.6507 \\
\hline $\mathrm{C}$ & -2.2958 & 0.0045 & 0.5074 & C & -2.2963 & -0.0445 & 0.5025 \\
\hline O & -1.535 & -0.0513 & -0.4445 & 0 & -1.5351 & 0.0482 & -0.4461 \\
\hline 0 & -3.0553 & -0.0155 & 3.8782 & 0 & -3.054 & -0.5696 & 3.8327 \\
\hline $\mathrm{N}$ & -4.1729 & 0.1794 & 1.8522 & $\mathrm{~N}$ & -4.1754 & -0.0942 & 1.8558 \\
\hline $\mathrm{H}$ & -5.07 & -0.1062 & 2.2133 & $\mathrm{H}$ & -5.0674 & -0.4456 & 2.1686 \\
\hline $\mathrm{N}$ & -1.9555 & 0.0373 & 1.8209 & $\mathrm{~N}$ & -1.956 & -0.1991 & 1.8075 \\
\hline $\mathrm{H}$ & -0.9798 & 0.0214 & 2.1467 & $\mathrm{H}$ & -0.9801 & -0.2508 & 2.1289 \\
\hline $\mathrm{C}$ & -3.8476 & 0.0619 & 0.4258 & C & -3.8492 & 0.0043 & 0.4283 \\
\hline $\mathrm{C}$ & 4.4776 & 1.2334 & 0.0219 & C & 4.4701 & -1.2782 & -0.1222 \\
\hline $\mathrm{C}$ & 4.042 & 2.3669 & -0.6703 & C & 4.0241 & -2.3266 & -0.9321 \\
\hline $\mathrm{C}$ & 4.7905 & 3.5456 & -0.6377 & $\mathrm{C}$ & 4.7661 & -3.5053 & -1.0346 \\
\hline
\end{tabular}




\begin{tabular}{|c|c|c|c|c|c|c|c|}
\hline C & 5.9781 & 3.6071 & 0.0878 & C & 5.9576 & -3.6527 & -0.3279 \\
\hline C & 6.4223 & 2.4774 & 0.7773 & C & 6.4114 & -2.6088 & 0.4802 \\
\hline C & 5.6804 & 1.2993 & 0.7389 & C & 5.6759 & -1.4299 & 0.5766 \\
\hline C & 4.4857 & -1.3043 & -0.2435 & C & 4.4939 & 1.2735 & -0.1017 \\
\hline C & 4.4787 & -2.4362 & 0.575 & C & 4.4901 & 2.3094 & 0.8355 \\
\hline C & 5.2268 & -3.5643 & 0.2295 & C & 5.2427 & 3.4654 & 0.615 \\
\hline C & 5.9787 & -3.5753 & -0.943 & C & 5.9957 & 3.6011 & -0.549 \\
\hline C & 5.979 & -2.4504 & -1.7706 & C & 5.9931 & 2.5729 & -1.4942 \\
\hline C & 5.2403 & -1.3223 & -1.4239 & C & 5.2502 & 1.4166 & -1.2724 \\
\hline $\mathrm{H}$ & 3.1311 & 2.3367 & -1.2544 & $\mathrm{H}$ & 3.1103 & -2.2273 & -1.5037 \\
\hline $\mathrm{H}$ & 4.4404 & 4.4135 & -1.1848 & $\mathrm{H}$ & 4.4087 & -4.3054 & -1.6728 \\
\hline $\mathrm{H}$ & 6.5568 & 4.5234 & 0.1117 & $\mathrm{H}$ & 6.5315 & -4.5686 & -0.4097 \\
\hline $\mathrm{H}$ & 7.3496 & 2.51 & 1.3381 & $\mathrm{H}$ & 7.3411 & -2.7077 & 1.0289 \\
\hline $\mathrm{H}$ & 6.0472 & 0.4206 & 1.2586 & $\mathrm{H}$ & 6.0502 & -0.6159 & 1.1883 \\
\hline $\mathrm{H}$ & 3.8883 & -2.4417 & 1.4826 & $\mathrm{H}$ & 3.8976 & 2.2187 & 1.7372 \\
\hline $\mathrm{H}$ & 5.2154 & -4.4322 & 0.8791 & $\mathrm{H}$ & 5.2335 & 4.2579 & 1.3549 \\
\hline $\mathrm{H}$ & 6.5584 & -4.4509 & -1.2123 & $\mathrm{H}$ & 6.5784 & 4.4989 & -0.7211 \\
\hline $\mathrm{H}$ & 6.556 & -2.45 & -2.6885 & $\mathrm{H}$ & 6.5711 & 2.6705 & -2.4061 \\
\hline $\mathrm{H}$ & 5.2436 & -0.4561 & -2.0737 & $\mathrm{H}$ & 5.2509 & 0.6258 & -2.012 \\
\hline C & 1.6371 & -0.0722 & 1.3277 & C & 1.6371 & -0.1061 & 1.3229 \\
\hline C & 2.4041 & -0.0279 & -0.8409 & C & 2.4048 & 0.0857 & -0.8374 \\
\hline o & 2.4101 & 0.0153 & -2.0462 & 0 & 2.4109 & 0.173 & -2.0403 \\
\hline O & 0.8534 & -0.0162 & 2.2647 & o & 0.8526 & -0.2627 & 2.2478 \\
\hline $\mathrm{N}$ & 2.995 & -0.161 & 1.4039 & $\mathrm{~N}$ & 2.9956 & -0.0386 & 1.4079 \\
\hline $\mathrm{H}$ & 3.454 & 0.0979 & 2.2634 & $\mathrm{H}$ & 3.452 & -0.3947 & 2.2333 \\
\hline $\mathrm{N}$ & 1.3004 & -0.0659 & -0.0213 & $\mathrm{~N}$ & 1.3011 & 0.0431 & -0.0181 \\
\hline $\mathrm{H}$ & 0.3211 & -0.0562 & -0.3313 & $\mathrm{H}$ & 0.322 & 0.0741 & -0.3271 \\
\hline $\mathrm{C}$ & 3.6547 & -0.0605 & 0.0955 & $\mathrm{C}$ & 3.6553 & 0.0043 & 0.0965 \\
\hline $4 \mathrm{AA}$ & & & & $4 \mathrm{AB}$ & & & \\
\hline $\mathrm{C}$ & -0.161 & -4.2987 & 1.2375 & $\begin{array}{l}\mathrm{C} \\
\mathrm{n}\end{array}$ & -4.2586 & 1.2326 & -0.0102 \\
\hline C & 0.2475 & -3.6739 & 2.4196 & C & -3.5902 & 2.3472 & 0.5057 \\
\hline C & 0.5266 & -4.4294 & 3.5598 & C & -4.3049 & 3.4707 & 0.9241 \\
\hline C & 0.3964 & -5.8164 & 3.535 & C & -5.6948 & 3.497 & 0.8281 \\
\hline C & -0.0098 & -6.448 & 2.3585 & C & -6.3697 & 2.3883 & 0.3153 \\
\hline C & -0.2809 & -5.6949 & 1.2182 & C & -5.6569 & 1.2637 & -0.0955 \\
\hline C & 0.0524 & -4.0779 & -1.2991 & C & -4.1199 & -1.3178 & -0.1129 \\
\hline C & -0.7211 & -4.3234 & -2.436 & C & -4.4154 & -2.3372 & -1.021 \\
\hline C & -0.1287 & -4.8165 & -3.6011 & C & -4.9421 & -3.5515 & -0.5739 \\
\hline C & 1.2426 & -5.0571 & -3.6435 & C & -5.1671 & -3.7612 & 0.7848 \\
\hline C & 2.0218 & -4.8022 & -2.5128 & C & -4.8636 & -2.7484 & 1.6973 \\
\hline C & 1.432 & -4.3179 & -1.3482 & C & -4.3459 & -1.5347 & 1.2529 \\
\hline $\mathrm{H}$ & 0.3684 & -2.5987 & 2.4589 & $\mathrm{H}$ & -2.5116 & 2.346 & 0.6003 \\
\hline $\mathrm{H}$ & 0.8495 & -3.9285 & 4.4654 & $\mathrm{H}$ & -3.77 & 4.3227 & 1.3279 \\
\hline $\mathrm{H}$ & 0.6148 & -6.4013 & 4.4211 & $\mathrm{H}$ & -6.2482 & 4.3699 & 1.1547 \\
\hline $\mathrm{H}$ & -0.1076 & -7.5271 & 2.3244 & $\mathrm{H}$ & -7.4513 & 2.394 & 0.2421 \\
\hline $\mathrm{H}$ & -0.5737 & -6.1978 & 0.3031 & $\mathrm{H}$ & -6.193 & 0.3998 & -0.4726 \\
\hline $\mathrm{H}$ & -1.7857 & -4.1279 & -2.4142 & $\mathrm{H}$ & -4.2327 & -2.1858 & -2.0772 \\
\hline
\end{tabular}




\begin{tabular}{|c|c|c|c|c|c|c|c|}
\hline $\mathrm{H}$ & -0.7437 & -5.0073 & -4.4733 & $\mathrm{H}$ & -5.1716 & -4.3308 & -1.2918 \\
\hline $\mathrm{H}$ & 1.7027 & -5.4379 & -4.5483 & $\mathrm{H}$ & -5.5736 & -4.7043 & 1.1321 \\
\hline $\mathrm{H}$ & 3.0908 & -4.9803 & -2.5366 & $\mathrm{H}$ & -5.0294 & -2.9028 & 2.7574 \\
\hline $\mathrm{H}$ & 2.0445 & -4.1203 & -0.4774 & $\mathrm{H}$ & -4.1104 & -0.7565 & 1.968 \\
\hline C & -2.4924 & -2.1173 & 0.073 & C & -2.1211 & 0.3046 & -2.4777 \\
\hline C & -0.1911 & -2.0029 & 0.0801 & C & -2.0029 & 0.0165 & -0.1946 \\
\hline 0 & 0.941 & -1.553 & 0.1265 & 0 & -1.5501 & -0.0968 & 0.9314 \\
\hline o & -3.6372 & -1.7458 & 0.1785 & 0 & -1.7486 & 0.542 & -3.6023 \\
\hline $\mathrm{N}$ & -2.0301 & -3.4003 & -0.091 & $\mathrm{~N}$ & -3.4076 & 0.1172 & -2.0337 \\
\hline $\mathrm{H}$ & -2.6316 & -4.1625 & 0.1808 & $\mathrm{H}$ & -4.1626 & 0.4845 & -2.5921 \\
\hline $\mathrm{N}$ & -1.35 & -1.2941 & 0.0892 & $\mathrm{~N}$ & -1.296 & 0.1554 & -1.3465 \\
\hline $\mathrm{H}$ & -1.3793 & -0.2684 & 0.1187 & $\mathrm{H}$ & -0.2701 & 0.1725 & -1.3748 \\
\hline C & -0.5684 & -3.5086 & -0.0144 & C & -3.5115 & 0.0151 & -0.5731 \\
\hline C & 0.161 & 4.2987 & 1.2375 & C & 4.2586 & -1.2326 & 0.0102 \\
\hline C & -0.2475 & 3.6739 & 2.4196 & C & 3.5902 & -2.3472 & -0.5057 \\
\hline C & -0.5266 & 4.4294 & 3.5598 & C & 4.3049 & -3.4707 & -0.9241 \\
\hline C & -0.3964 & 5.8164 & 3.535 & C & 5.6948 & -3.497 & -0.8281 \\
\hline C & 0.0098 & 6.448 & 2.3585 & C & 6.3697 & -2.3883 & -0.3153 \\
\hline C & 0.2809 & 5.6949 & 1.2182 & C & 5.6569 & -1.2637 & 0.0955 \\
\hline C & -0.0524 & 4.0779 & -1.2991 & C & 4.1199 & 1.3178 & 0.1129 \\
\hline C & 0.7211 & 4.3234 & -2.436 & C & 4.4154 & 2.3372 & 1.021 \\
\hline C & 0.1287 & 4.8165 & -3.6011 & C & 4.9421 & 3.5515 & 0.5739 \\
\hline C & -1.2426 & 5.0571 & -3.6435 & C & 5.1671 & 3.7612 & -0.7848 \\
\hline C & -2.0218 & 4.8022 & -2.5128 & C & 4.8636 & 2.7484 & -1.6973 \\
\hline C & -1.432 & 4.3179 & -1.3482 & C & 4.3459 & 1.5347 & -1.2529 \\
\hline $\mathrm{H}$ & -0.3684 & 2.5987 & 2.4589 & $\mathrm{H}$ & 2.5116 & -2.346 & -0.6003 \\
\hline $\mathrm{H}$ & -0.8495 & 3.9285 & 4.4654 & $\mathrm{H}$ & 3.77 & -4.3227 & -1.3279 \\
\hline $\mathrm{H}$ & -0.6148 & 6.4013 & 4.4211 & $\mathrm{H}$ & 6.2482 & -4.3699 & -1.1547 \\
\hline $\mathrm{H}$ & 0.1076 & 7.5271 & 2.3244 & $\mathrm{H}$ & 7.4513 & -2.394 & -0.2421 \\
\hline $\mathrm{H}$ & 0.5737 & 6.1978 & 0.3031 & $\mathrm{H}$ & 6.193 & -0.3998 & 0.4726 \\
\hline $\mathrm{H}$ & 1.7857 & 4.1279 & -2.4142 & $\mathrm{H}$ & 4.2327 & 2.1858 & 2.0772 \\
\hline $\mathrm{H}$ & 0.7437 & 5.0073 & -4.4733 & $\mathrm{H}$ & 5.1716 & 4.3308 & 1.2918 \\
\hline $\mathrm{H}$ & -1.7027 & 5.4379 & -4.5483 & $\mathrm{H}$ & 5.5736 & 4.7043 & -1.1321 \\
\hline $\mathrm{H}$ & -3.0908 & 4.9803 & -2.5366 & $\mathrm{H}$ & 5.0294 & 2.9028 & -2.7574 \\
\hline $\mathrm{H}$ & -2.0445 & 4.1203 & -0.4774 & $\mathrm{H}$ & 4.1104 & 0.7565 & -1.968 \\
\hline C & 2.4924 & 2.1173 & 0.073 & C & 2.1211 & -0.3046 & 2.4777 \\
\hline C & 0.1911 & 2.0029 & 0.0801 & C & 2.0029 & -0.0165 & 0.1946 \\
\hline 0 & -0.941 & 1.553 & 0.1265 & 0 & 1.5501 & 0.0968 & -0.9314 \\
\hline 0 & 3.6372 & 1.7458 & 0.1785 & 0 & 1.7486 & -0.542 & 3.6023 \\
\hline $\mathrm{N}$ & 2.0301 & 3.4003 & -0.091 & $\mathrm{~N}$ & 3.4076 & -0.1172 & 2.0337 \\
\hline $\mathrm{H}$ & 2.6316 & 4.1625 & 0.1808 & $\mathrm{H}$ & 4.1626 & -0.4845 & 2.5921 \\
\hline $\mathrm{N}$ & 1.35 & 1.2941 & 0.0892 & $\mathrm{~N}$ & 1.296 & -0.1554 & 1.3465 \\
\hline $\mathrm{H}$ & 1.3793 & 0.2684 & 0.1187 & $\mathrm{H}$ & 0.2701 & -0.1725 & 1.3748 \\
\hline $\mathrm{C}$ & 0.5684 & 3.5086 & -0.0144 & C & 3.5115 & -0.0151 & 0.5731 \\
\hline $5 \mathrm{AA}$ & & & & $5 \mathrm{AB}$ & & & \\
\hline C & -4.3168 & 1.316 & -0.2802 & C & -4.2245 & 1.2912 & -0.1974 \\
\hline $\mathrm{C}$ & -4.197 & 2.4366 & 0.5469 & $\mathrm{C}$ & -3.9706 & 2.362 & 0.6653 \\
\hline
\end{tabular}




\begin{tabular}{|c|c|c|c|c|c|c|c|}
\hline C & -4.8815 & 3.6154 & 0.243 & C & -4.5661 & 3.6051 & 0.4442 \\
\hline C & -5.6884 & 3.6905 & -0.8903 & C & -5.4177 & 3.7955 & -0.6421 \\
\hline C & -5.8158 & 2.5746 & -1.7192 & C & -5.6784 & 2.7309 & -1.5063 \\
\hline C & -5.1393 & 1.3962 & -1.4127 & C & -5.0899 & 1.4881 & -1.282 \\
\hline C & -4.4053 & -1.2287 & -0.1074 & C & -4.4872 & -1.2484 & -0.1907 \\
\hline C & -4.0502 & -2.3385 & -0.8778 & C & -4.2328 & -2.3056 & -1.0676 \\
\hline C & -4.8592 & -3.4773 & -0.894 & C & -5.1217 & -3.3795 & -1.1585 \\
\hline C & -6.0235 & -3.5214 & -0.1307 & C & -6.266 & -3.4119 & -0.3651 \\
\hline C & -6.3764 & -2.4187 & 0.6502 & C & -6.5185 & -2.363 & 0.5217 \\
\hline C & -5.5758 & -1.2798 & 0.6611 & C & -5.638 & -1.288 & 0.6079 \\
\hline $\mathrm{H}$ & -3.5894 & 2.3951 & 1.4418 & $\mathrm{H}$ & -3.3249 & 2.2333 & 1.5248 \\
\hline $\mathrm{H}$ & -4.7829 & 4.4725 & 0.8994 & $\mathrm{H}$ & -4.3635 & 4.4218 & 1.1277 \\
\hline $\mathrm{H}$ & -6.2192 & 4.6065 & -1.1232 & $\mathrm{H}$ & -5.8798 & 4.7614 & -0.8112 \\
\hline $\mathrm{H}$ & -6.4481 & 2.6174 & -2.5988 & $\mathrm{H}$ & -6.3459 & 2.8639 & -2.3502 \\
\hline $\mathrm{H}$ & -5.2651 & 0.5273 & -2.0498 & $\mathrm{H}$ & -5.3174 & 0.6619 & -1.9467 \\
\hline $\mathrm{H}$ & -3.1403 & -2.3188 & -1.4641 & $\mathrm{H}$ & -3.3394 & -2.2961 & -1.6792 \\
\hline $\mathrm{H}$ & -4.5719 & -4.328 & -1.5017 & $\mathrm{H}$ & -4.9124 & -4.1895 & -1.8481 \\
\hline $\mathrm{H}$ & -6.6502 & -4.406 & -0.1407 & $\mathrm{H}$ & -6.9547 & -4.2464 & -0.4334 \\
\hline $\mathrm{H}$ & -7.277 & -2.4448 & 1.2532 & $\mathrm{H}$ & -7.4027 & -2.3813 & 1.1488 \\
\hline $\mathrm{H}$ & -5.8551 & -0.4318 & 1.2736 & $\mathrm{H}$ & -5.8385 & -0.4815 & 1.302 \\
\hline C & -1.177 & 0.0358 & -0.3338 & C & -1.1801 & -0.1662 & -0.3527 \\
\hline C & -2.7675 & 0.028 & 1.3249 & C & -2.765 & -0.1974 & 1.3108 \\
\hline 0 & -3.2709 & 0.0452 & 2.4205 & 0 & -3.2645 & -0.2269 & 2.4079 \\
\hline o & -0.0769 & 0.1139 & -0.8656 & o & -0.0788 & -0.1079 & -0.8844 \\
\hline $\mathrm{N}$ & -2.3822 & -0.0397 & -0.9663 & $\mathrm{~N}$ & -2.3893 & -0.1446 & -0.9834 \\
\hline $\mathrm{H}$ & -2.4485 & 0.2477 & -1.9303 & $\mathrm{H}$ & -2.4404 & 0.2181 & -1.9229 \\
\hline $\mathrm{N}$ & -1.4236 & 0.0023 & 1.0326 & $\mathrm{~N}$ & -1.4249 & -0.2748 & 1.01 \\
\hline $\mathrm{H}$ & -0.6581 & 0.0011 & 1.7237 & $\mathrm{H}$ & -0.659 & -0.3544 & 1.6961 \\
\hline C & -3.5226 & 0.0241 & -0.0435 & C & -3.5217 & -0.066 & -0.0506 \\
\hline C & 3.9674 & -1.3109 & -0.3628 & C & 3.9467 & 1.3016 & -0.1988 \\
\hline C & 4.7654 & -2.3667 & 0.0839 & C & 4.7738 & 2.2821 & 0.3542 \\
\hline C & 4.9439 & -3.5019 & -0.7119 & C & 4.9405 & 3.5109 & -0.2913 \\
\hline C & 4.3288 & -3.5945 & -1.9575 & C & 4.2853 & 3.7719 & -1.4916 \\
\hline C & 3.5318 & -2.5404 & -2.41 & C & 3.4598 & 2.7936 & -2.0505 \\
\hline C & 3.3566 & -1.4075 & -1.6211 & C & 3.2955 & 1.5682 & -1.4116 \\
\hline C & 4.2662 & 1.2118 & -0.2129 & C & 4.272 & -1.2189 & -0.3683 \\
\hline C & 3.4924 & 2.362 & -0.3849 & C & 3.5268 & -2.3709 & -0.6318 \\
\hline C & 4.0387 & 3.4972 & -0.988 & C & 4.0835 & -3.42 & -1.3664 \\
\hline C & 5.3647 & 3.4966 & -1.4144 & C & 5.3926 & -3.3325 & -1.8346 \\
\hline C & 6.144 & 2.3514 & -1.2375 & C & 6.1437 & -2.1864 & -1.5664 \\
\hline C & 5.5986 & 1.2157 & -0.6451 & C & 5.5875 & -1.1357 & -0.8417 \\
\hline $\mathrm{H}$ & 5.2666 & -2.3083 & 1.041 & $\mathrm{H}$ & 5.3053 & 2.0935 & 1.2776 \\
\hline $\mathrm{H}$ & 5.5686 & -4.3111 & -0.3507 & $\mathrm{H}$ & 5.5871 & 4.2601 & 0.1515 \\
\hline $\mathrm{H}$ & 4.4688 & -4.4762 & -2.5724 & $\mathrm{H}$ & 4.4157 & 4.7258 & -1.9899 \\
\hline $\mathrm{H}$ & 3.049 & -2.5979 & -3.3789 & $\mathrm{H}$ & 2.9452 & 2.9828 & -2.9857 \\
\hline $\mathrm{H}$ & 2.7405 & -0.5944 & -1.9892 & $\mathrm{H}$ & 2.655 & 0.8176 & -1.8616 \\
\hline $\mathrm{H}$ & 2.4619 & 2.3766 & -0.0536 & $\mathrm{H}$ & 2.5097 & -2.4524 & -0.2701 \\
\hline $\mathrm{H}$ & 3.4227 & 4.3795 & -1.121 & $\mathrm{H}$ & 3.4892 & -4.304 & -1.5687 \\
\hline
\end{tabular}




\begin{tabular}{|c|c|c|c|c|c|c|c|}
\hline $\mathrm{H}$ & 5.7889 & 4.3785 & -1.8811 & $\mathrm{H}$ & 5.8251 & -4.1477 & -2.4036 \\
\hline $\mathrm{H}$ & 7.1779 & 2.3406 & -1.5634 & $\mathrm{H}$ & 7.1644 & -2.1083 & -1.9234 \\
\hline $\mathrm{H}$ & 6.2096 & 0.3318 & -0.5123 & $\mathrm{H}$ & 6.1777 & -0.2509 & -0.6396 \\
\hline C & 1.9963 & -0.0042 & 2.0952 & $\mathrm{C}$ & 1.9935 & -0.3274 & 2.0738 \\
\hline C & 4.2966 & -0.1376 & 1.9077 & $\mathrm{C}$ & 4.292 & -0.1462 & 1.9041 \\
\hline o & 5.46 & -0.2152 & 2.2205 & 0 & 5.4552 & -0.1001 & 2.2236 \\
\hline O & 0.9038 & 0.0083 & 2.65 & 0 & 0.9019 & -0.426 & 2.6218 \\
\hline N & 2.2745 & 0.0709 & 0.7777 & $\mathrm{~N}$ & 2.2708 & -0.2325 & 0.7574 \\
\hline $\mathrm{H}$ & 1.5166 & 0.0574 & 0.0897 & $\mathrm{H}$ & 1.5118 & -0.1433 & 0.0762 \\
\hline $\mathrm{N}$ & 3.2215 & -0.1015 & 2.7645 & $\mathrm{~N}$ & 3.2183 & -0.2975 & 2.7503 \\
\hline $\mathrm{H}$ & 3.2929 & -0.1364 & 3.7702 & $\mathrm{H}$ & 3.2912 & -0.3921 & 3.752 \\
\hline $\mathrm{C}$ & 3.7019 & -0.044 & 0.4691 & $\mathrm{C}$ & 3.6962 & -0.0635 & 0.4652 \\
\hline $6 \mathrm{AA}$ & & & & $6 \mathrm{AB}$ & & & \\
\hline C & -0.068 & -3.714 & 1.2822 & C & -3.7584 & -1.3196 & 0.0043 \\
\hline $\mathrm{C}$ & 0.6478 & -4.3649 & 2.2895 & $\mathrm{C}$ & -4.4127 & -2.2848 & -0.7648 \\
\hline C & 0.0109 & -4.7454 & 3.4743 & $\mathrm{C}$ & -4.8268 & -3.4873 & -0.1844 \\
\hline C & -1.3424 & -4.4799 & 3.6645 & $\mathrm{C}$ & -4.5914 & -3.7375 & 1.1647 \\
\hline C & -2.0633 & -3.8317 & 2.659 & $\mathrm{C}$ & -3.9396 & -2.7746 & 1.9387 \\
\hline C & -1.4323 & -3.4558 & 1.477 & $\mathrm{C}$ & -3.5306 & -1.575 & 1.364 \\
\hline $\mathrm{C}$ & -0.0023 & -3.999 & -1.2455 & $\mathrm{C}$ & -3.9643 & 1.2173 & 0.058 \\
\hline C & -0.4799 & -3.3251 & -2.3721 & $\mathrm{C}$ & -3.255 & 2.313 & 0.556 \\
\hline C & -0.9775 & -4.0392 & -3.4645 & $\mathrm{C}$ & -3.9336 & 3.4061 & 1.0994 \\
\hline C & -0.992 & -5.4318 & -3.4454 & $\mathrm{C}$ & -5.3258 & 3.4189 & 1.1401 \\
\hline C & -0.5089 & -6.1095 & -2.324 & $\mathrm{C}$ & -6.0389 & 2.3289 & 0.6365 \\
\hline $\mathrm{C}$ & -0.0215 & -5.3996 & -1.2301 & $\mathrm{C}$ & -5.3642 & 1.2343 & 0.1026 \\
\hline $\mathrm{H}$ & 1.6966 & -4.5951 & 2.1557 & $\mathrm{H}$ & -4.6208 & -2.1041 & -1.8112 \\
\hline $\mathrm{H}$ & 0.5812 & -5.2513 & 4.2453 & $\mathrm{H}$ & -5.3358 & -4.2245 & -0.7951 \\
\hline $\mathrm{H}$ & -1.8337 & -4.7753 & 4.5846 & $\mathrm{H}$ & -4.9131 & -4.6711 & 1.6121 \\
\hline $\mathrm{H}$ & -3.1181 & -3.6204 & 2.7932 & $\mathrm{H}$ & -3.7514 & -2.9556 & 2.9908 \\
\hline $\mathrm{H}$ & -2.007 & -2.9572 & 0.7041 & $\mathrm{H}$ & -3.0301 & -0.8353 & 1.9791 \\
\hline $\mathrm{H}$ & -0.4721 & -2.2431 & -2.4012 & $\mathrm{H}$ & -2.1729 & 2.3167 & 0.5269 \\
\hline $\mathrm{H}$ & -1.3524 & -3.5009 & -4.3277 & $\mathrm{H}$ & -3.3681 & 4.2451 & 1.4889 \\
\hline $\mathrm{H}$ & -1.377 & -5.9859 & -4.294 & $\mathrm{H}$ & -5.8524 & 4.2681 & 1.5606 \\
\hline $\mathrm{H}$ & -0.5138 & -7.1933 & -2.2989 & $\mathrm{H}$ & -7.1227 & 2.329 & 0.6611 \\
\hline $\mathrm{H}$ & 0.3501 & -5.9336 & -0.3648 & $\mathrm{H}$ & -5.9254 & 0.3934 & -0.2849 \\
\hline C & 1.6315 & -1.1425 & -0.1721 & $\mathrm{C}$ & -1.1431 & 0.1376 & -1.6262 \\
\hline C & 2.1213 & -3.3982 & -0.037 & $\mathrm{C}$ & -3.402 & 0.0951 & -2.1192 \\
\hline 0 & 2.7606 & -4.421 & 0.011 & 0 & -4.4258 & 0.1073 & -2.7585 \\
\hline 0 & 1.847 & 0.0636 & -0.2193 & 0 & 0.0637 & 0.1551 & -1.8409 \\
\hline $\mathrm{N}$ & 0.4484 & -1.7884 & -0.1673 & $\mathrm{~N}$ & -1.7887 & 0.0925 & -0.4432 \\
\hline $\mathrm{H}$ & -0.4313 & -1.2637 & -0.1378 & $\mathrm{H}$ & -1.2664 & -0.0378 & 0.4289 \\
\hline $\mathrm{N}$ & 2.6293 & -2.1221 & -0.1141 & $\mathrm{~N}$ & -2.1242 & 0.1646 & -2.624 \\
\hline $\mathrm{H}$ & 3.6135 & -1.9028 & -0.142 & $\mathrm{H}$ & -1.904 & 0.2407 & -3.6054 \\
\hline C & 0.5702 & -3.2427 & -0.0369 & C & -3.2469 & 0.0128 & -0.5703 \\
\hline C & 0.068 & 3.714 & 1.2822 & $\mathrm{C}$ & 3.7584 & 1.3196 & -0.0043 \\
\hline C & -0.6478 & 4.3649 & 2.2895 & $\mathrm{C}$ & 4.4127 & 2.2848 & 0.7648 \\
\hline $\mathrm{C}$ & -0.0109 & 4.7454 & 3.4743 & $\mathrm{C}$ & 4.8268 & 3.4873 & 0.1844 \\
\hline
\end{tabular}




\begin{tabular}{|c|c|c|c|c|c|c|c|}
\hline $\mathrm{C}$ & 1.3424 & 4.4799 & 3.6645 & C & 4.5914 & 3.7375 & -1.1647 \\
\hline C & 2.0633 & 3.8317 & 2.659 & C & 3.9396 & 2.7746 & -1.9387 \\
\hline C & 1.4323 & 3.4558 & 1.477 & C & 3.5306 & 1.575 & -1.364 \\
\hline C & 0.0023 & 3.999 & -1.2455 & C & 3.9643 & -1.2173 & -0.058 \\
\hline C & 0.4799 & 3.3251 & -2.3721 & C & 3.255 & -2.313 & -0.556 \\
\hline C & 0.9775 & 4.0392 & -3.4645 & C & 3.9336 & -3.4061 & -1.0994 \\
\hline C & 0.992 & 5.4318 & -3.4454 & C & 5.3258 & -3.4189 & -1.1401 \\
\hline C & 0.5089 & 6.1095 & -2.324 & C & 6.0389 & -2.3289 & -0.6365 \\
\hline C & 0.0215 & 5.3996 & -1.2301 & C & 5.3642 & -1.2343 & -0.1026 \\
\hline $\mathrm{H}$ & -1.6966 & 4.5951 & 2.1557 & $\mathrm{H}$ & 4.6208 & 2.1041 & 1.8112 \\
\hline $\mathrm{H}$ & -0.5812 & 5.2513 & 4.2453 & $\mathrm{H}$ & 5.3358 & 4.2245 & 0.7951 \\
\hline $\mathrm{H}$ & 1.8337 & 4.7753 & 4.5846 & $\mathrm{H}$ & 4.9131 & 4.6711 & -1.6121 \\
\hline $\mathrm{H}$ & 3.1181 & 3.6204 & 2.7932 & $\mathrm{H}$ & 3.7514 & 2.9556 & -2.9908 \\
\hline $\mathrm{H}$ & 2.007 & 2.9572 & 0.7041 & $\mathrm{H}$ & 3.0301 & 0.8353 & -1.9791 \\
\hline $\mathrm{H}$ & 0.4721 & 2.2431 & -2.4012 & $\mathrm{H}$ & 2.1729 & -2.3167 & -0.5269 \\
\hline $\mathrm{H}$ & 1.3524 & 3.5009 & -4.3277 & $\mathrm{H}$ & 3.3681 & -4.2451 & -1.4889 \\
\hline $\mathrm{H}$ & 1.377 & 5.9859 & -4.294 & $\mathrm{H}$ & 5.8524 & -4.2681 & -1.5606 \\
\hline $\mathrm{H}$ & 0.5138 & 7.1933 & -2.2989 & $\mathrm{H}$ & 7.1227 & -2.329 & -0.6611 \\
\hline $\mathrm{H}$ & -0.3501 & 5.9336 & -0.3648 & $\mathrm{H}$ & 5.9254 & -0.3934 & 0.2849 \\
\hline C & -1.6315 & 1.1425 & -0.1721 & C & 1.1431 & -0.1376 & 1.6262 \\
\hline C & -2.1213 & 3.3982 & -0.037 & C & 3.402 & -0.0951 & 2.1192 \\
\hline 0 & -2.7606 & 4.421 & 0.011 & 0 & 4.4258 & -0.1073 & 2.7585 \\
\hline o & -1.847 & -0.0636 & -0.2193 & 0 & -0.0637 & -0.1551 & 1.8409 \\
\hline $\mathrm{N}$ & -0.4484 & 1.7884 & -0.1673 & $\mathrm{~N}$ & 1.7887 & -0.0925 & 0.4432 \\
\hline $\mathrm{H}$ & 0.4313 & 1.2637 & -0.1378 & $\mathrm{H}$ & 1.2664 & 0.0378 & -0.4289 \\
\hline $\mathrm{N}$ & -2.6293 & 2.1221 & -0.1141 & $\mathrm{~N}$ & 2.1242 & -0.1646 & 2.624 \\
\hline $\mathrm{H}$ & -3.6135 & 1.9028 & -0.142 & $\mathrm{H}$ & 1.904 & -0.2407 & 3.6054 \\
\hline C & -0.5702 & 3.2427 & -0.0369 & C & 3.2469 & -0.0128 & 0.5703 \\
\hline
\end{tabular}

